\title{
Irrigated afforestation of the Sahara and Australian Outback to end global warming
}

\author{
Leonard Ornstein · Igor Aleinov • David Rind
}

Received: 14 January 2008 / Accepted: 28 April 2009 / Published online: 19 August 2009

(C) The Author(s) 2009. This article is published with open access at Springerlink.com

\begin{abstract}
Each year, irrigated Saharan- and Australian-desert forests could sequester amounts of atmospheric $\mathrm{CO}_{2}$ at least equal to that from burning fossil fuels. Without any rain, to capture $\mathrm{CO}_{2}$ produced from gasoline requires adding about $\$ 1$ to the per-gallon pump-price to cover irrigation costs, using reverse osmosis (RO), desalinated, sea water. Such mature technology is economically competitive with the currently favored, untested, power-plant Carbon Capture (and deep underground, or under-ocean) Sequestration (CCS). Afforestation sequesters $\mathrm{CO}_{2}$, mostly as easily
\end{abstract}

Electronic supplementary material The online version of this article (doi: 10.1007/s10584-009-9626-y) contains supplementary material, which is available to authorized users.

L. Ornstein $(\varangle)$

Department of Pathology, Mount Sinai School of Medicine,

New York, NY 10029, USA

e-mail: lenornst@pipeline.com

L. Ornstein

5 Biltom Road, White Plains, NY 10607, USA

I. Aleinov

Earth Institute, Columbia University,

New York, NY 10025, USA

I. Aleinov $\cdot$ D. Rind

NASA Goddard Institute for Space Studies, 2880 Broadway,

New York, NY 10025, USA

I. Aleinov

e-mail: ialeinov@giss.nasa.gov

D. Rind

e-mail: drind@giss.nasa.gov

D. Rind

Department of Earth and Environmental Science, Columbia University,

New York, NY 10025, USA 
stored wood, both from distributed sources (automotive, aviation, etc., that CCS cannot address) and from power plants. Climatological feasibility and sustainability of such irrigated forests, and their potential global impacts are explored using a general circulation model (GCM). Biogeophysical feedback (Charney 1975) is shown to stimulate considerable rainfall over these forests, reducing desalination and irrigation costs; economic value of marketed, renewable, forest biomass, further reduces costs; and separately, energy conservation also reduces the size of the required forests and therefore their total capital and operating costs. The few negative climate impacts outside of the forests are discussed, with caveats. If confirmed with other GCMs, such irrigated, subtropical afforestation probably provides the best, nearterm route to complete control of green-house-gas-induced, global warming.

\section{Introduction}

About 7.2 $\pm 0.3 \mathrm{Gt}^{1}$ of carbon (C) from fossil fuel (estimated for 2000-2005), and an additional increment of about $1.6 \pm 0.9 \mathrm{Gt} C$ per year (estimated for the 1990s) consumed by burning and/or biodegradation following deforestation and 'land use', have been introduced annually into the atmosphere as $\mathrm{CO}_{2}$ (Alley et al. 2007). About $58 \%$ of this $\left(5.3 \mathrm{Gt} \mathrm{C}\right.$ per year $\approx 19 \mathrm{Gt} \mathrm{CO}_{2}$ per year $\approx 2 \mathrm{ppm} \mathrm{CO}_{2}$ per year) presently remains airborne (Hansen and Sato 2004). The rest of the anthropogenic $\mathrm{CO}_{2}$ is absorbed from the atmosphere by the oceans and biosphere (Battle et al. 2000). This increasing atmospheric concentration of $\mathrm{CO}_{2}$, is the major cause of global warming (Hansen et al. 1981). Although gradual in its effects, unabated, it may pose the greatest environmental challenge to humanity since the development of modern civilization.

Afforestation of temperate regions seems to have been rejected as a practical solution to warming because the additional net warming, from albedo decrease, almost cancels the cooling effects produced by the sequestration of $\mathrm{CO}_{2}$ by the trees (Bala et al. 2007).

But afforestation of subtropical regions, with broad-leaf evergreen trees with the potential for 12-month growing-seasons, is entirely another matter. The Sahara and the Australian Outback are two Hadley-Cell deserts; vast, subtropical, continental areas, where human occupation, agricultural food and fiber resources and competing natural biomes are minimal (only the Antarctic land mass is comparably vast and barren). Were either, or both, planted with irrigated forests, very large $\mathrm{CO}_{2}$ sinks would be generated.

In addition to proposing this 'cure', this report will provide a preliminary examination of other possible climatological impacts of such projects, and their potential for sustainability.

\section{The model}

If we define the Sahara as a swath, about $16^{\circ}$ latitude $\times 50^{\circ}$ longitude, (sum of the yellow and orange areas in Fig. 1a) this encompasses about $9.8 \times 10^{8}$ ha. At such

\footnotetext{
${ }_{1}^{1} \mathrm{Gt} \mathrm{C}$ per year $=10^{15} \mathrm{~g} \mathrm{C}$ per year $=0.47 \mathrm{ppm} \mathrm{CO}_{2}$ added to the atmosphere per year.
} 
AFFORESTATION AREAS

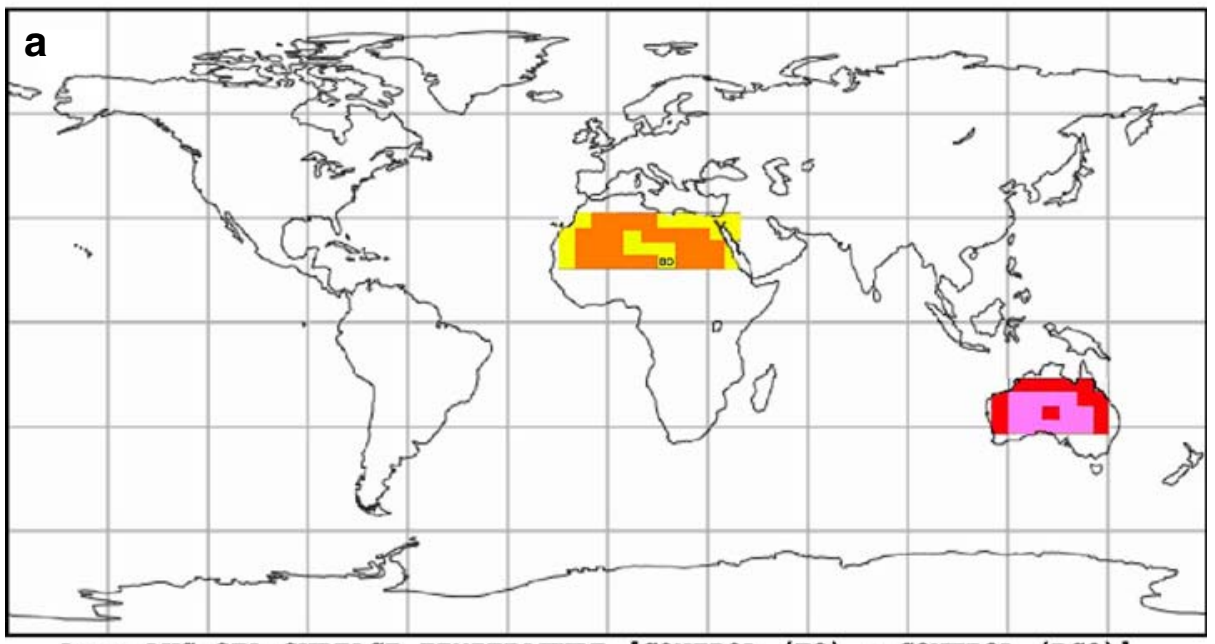

AnOm AUG SEA SURFACE TBMPERATURE [CONTROL (FO) - CONTROL (DCO)]

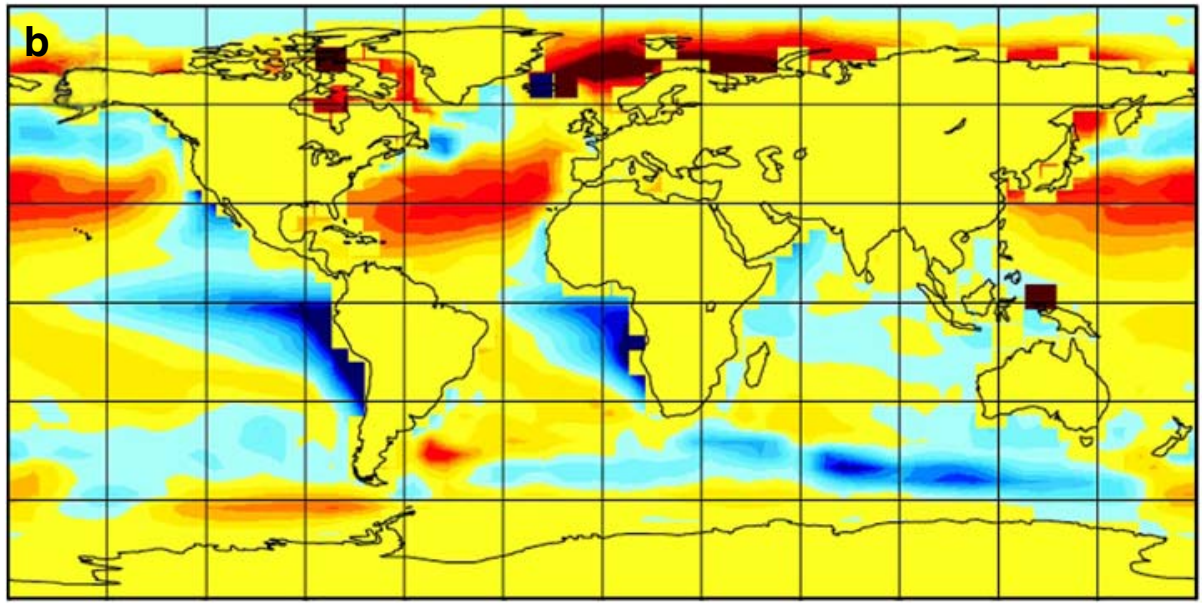

(SEA SURFACE TEMPERATURE - SEA SURFACE TEMPERATURE) (C)

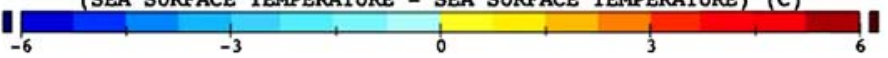

Fig. 1 a Illustrates which $4^{\circ} \times 5^{\circ}$ cells were modified with irrigation and Rain Forest (RF) for GCM runs: Yellow plus orange represent Sahara-Forest only runs [SRF fixed ocean (FO) and SRF dynamic coupled ocean (DCO)]. Red plus magenta represent Australian-Forest only runs [AuRF (FO) and AuRF (DCO)]. Orange plus magenta represent combined Sahara- and Australian-Forest runs [SRF/AuRF (FO) and SRF/AuRF (DCO)]. b The difference (anomaly) between the 10-year averages of August sea surface temperatures (SSTs) of the fixed-ocean-control and the dynamicocean-control (both without desert afforestation and irrigation)

latitudes, 5 to 8 year-old Eucalyptus plantations of about 1,000 trees per hectare can sequester aboveground, net, primary productivity (ANPP), from about 1 to $2 \times 10^{7} \mathrm{~g}$ dry mass per hectare per year $\left(\approx 0.5\right.$ to $1 \times 10^{7} \mathrm{~g} \mathrm{C}$ per hectare per year $)$. This is achieved with about $1,000 \mathrm{~mm} /$ year precipitation; the variation was attributed largely to differing soil fertility (Stape et al. 2004a). Underground carbon adds about 
another $20 \%$ to give the total NPP. High-efficiency irrigation (Howell 2001), can be at least twice as efficient as rainfall in delivering water to trees. Such irrigation is scheduled to just replace moisture consumed, so that virtually no losses occur due to runoff at the surface, to the soil below the root zone or to evaporation from wet foliage. This is managed by estimating local evapotranspiration, using either observations derived from satellites, local pan-evaporation or soil-moisture sensors in the root-zone. ${ }^{2}$ Therefore, irrigated with about $500 \mathrm{~mm} / \mathrm{year}$, the Sahara might sequester from about 6 to $12 \mathrm{Gt} \mathrm{C}$ per year in wood, bark, leaves and roots. Such a forest (of $\approx 100 \mathrm{~m}$-tall trees; e.g., Eucalyptus grandis) can accumulate carbon at such a rate for about a century, reaching a steady-state, when photosynthetic $\mathrm{CO}_{2}$ in = respiratory $\mathrm{CO}_{2}$ out. However, within a few decades of planting, a growing portion of such a forest could be harvested (and replanted), ramping up to a yield of about 7.2 Gt C per year, providing a 'forever' renewable carbon source, for marketing at less than the taxed prices of coal, oil and gas. Used for direct burning, conversion to liquid fuel (as a substitute for non-renewable, fossil fuels), conversion to synthetic feed-stock, construction use and/or storage, as credits against the burning of unrenewed biofuels or of fossil fuels, it could solve both the warming problem and the depletion of non-renewable fuels and organic feed-stocks. Ash and other inorganic residues would be recycled to the forest floor.

Such calculations combine a number of measurements with large error bars. The proposed model assumes that 'truth' falls within the approximations of these calculations.

The case for Australia is similar, but the comparable 'desert' has an area about $60 \%$ of that of the Sahara.

The Sahara and Australian Outback present tremendous infrastructural challenges. Installation of roads and aqueducts, in some areas might be prohibitive. But to "end" global warming, only sequestration of something like 7.2 Gt C per year is 'required', if deforestation and land abuse end; otherwise about $8.8 \mathrm{Gt} \mathrm{C}$ per year. Therefore, a more selective, culturally-compatible, restricted planting of the forests within the deserts may be possible, avoiding mountains and saline, toxic or other particularly infertile or inaccessible areas. Sufficient area might still remain for even further drawdown of atmospheric $\mathrm{CO}_{2}$, if desired.

But from where will the $500 \mathrm{~mm} /$ year irrigation water come, $\left(\approx 4.9 \times 10^{12} \mathrm{~m}^{3} /\right.$ year for the Sahara, as defined)? What will it cost? Over and above the global control of

\footnotetext{
${ }^{2}$ In a published address to the Electrophoresis Society, Ornstein (1987) discussed the paths to and from the invention, in 1959, of polyacrylamide gel electrophoresis (PAGE). He explained how his subsequent invention of the Irristat, a small, moisture-sensitive, self-regulating, irrigation valve (Ornstein 1980), that uses very slightly cross-linked polyacrylamide gel, as both a moisture sensor and valve actuator, led him, in 1980, to climatological speculations and then collaboration with Jim Hansen of GISS and Peter Stone of MIT.
}

When musing on its possibilities for agriculture in arid lands (see footnote 5), I tried to imagine the consequences of covering the Sahara Desert with a forest irrigated with the extensive fossil aquifers that lie beneath it. Unless the forest induced sufficient increase in natural rainfall by positive feedback (Charney et al. 1975), such a plan would eventually fail as the aquifers dried out. This has involved me with global weather modeling at the Goddard Institute for Space Studies in New York City (Hansen et al. 1981; Page 10, Ornstein 1987). 
atmospheric $\mathrm{CO}_{2}$ buildup and global warming, what will be the climatological consequences of such extensive terraforming: for example, on rainfall within the Sahara; on rainfall in the rest of the world; on Atlantic hurricanes; on the loss of the 'Sahara dust fertilization' of the Atlantic, Amazon and Caribbean; on Atlantic upwellings and the fisheries they support; and on the climate of surrounding countries?

Support for answers to these questions will be sought with simple calculations, with modeling of global climate with such irrigated forests 'installed' (Fig. 1a), using the GISS ModelE GCM (Schmidt et al. 2006; Friend and Kiang 2005) and with speculations about other testable models.

\subsection{Water and its cost}

Fresh water resources are rare in deserts. Precipitation over much of the Sahara ranges from 0 to only $40 \mathrm{~mm} /$ year; and 50 to $300 \mathrm{~mm} /$ year over much of the driest part of the Australian Outback.

Perhaps surprisingly, the world's largest, ground-water aquifers reside beneath the Sahara.

In the Sahara Desert, the major water resources are the Nubian Sandstone and the North Western Sahara nonrenewable aquifer systems, which extend from Egypt to Mauritania. The Nubian Sandstone Aquifer is a non-rechargeable reserve that was filled up during the humid periods of the pluvial age 8,000 years BC and before. The aquifer is shared by four countries: Egypt, Libya, Sudan, and Chad. Its area covers $2,350,000 \mathrm{~km}^{2}$, and it has a maximum reservoir capacity of $150,000 \mathrm{~km}^{3}\left(1.5 \times 10^{14} \mathrm{~m}^{3}\right)$. Geologically, this reservoir is made up of continental sand stones of Mesozoic and Cambro-Ordovician which extends all through the Sahara Desert and the Arab Peninsula (from the Atlantic Ocean to the Arabian Gulf) (Abu-Zeid et al. 2004).

The Nubian and other large fossil aquifers are illustrated in Fig. 2a (from CEOS TIGER-Workshop 2004). The Iullemeden Aquifer System is shared by Mali, Niger and Nigeria. Some of these were laid down during the Holocene, others 40k and $75 \mathrm{k}$ years ago and some during the previous interglacial, about $125 \mathrm{k}$ years ago (Zuppi and Sacchi 2004; Beyerle et al. 2003). They are nonrenewable and, at best, could only supply forest irrigation for a few years, to 'prime' a possibly sustainable, biogeophysical-feedback pump (to be discussed).

The only substantial, renewable water-resource in the Sahara is the Nile River. It has an average flow rate of about $2,830 \mathrm{~m}^{3} / \mathrm{s}\left(\approx 10^{11} \mathrm{~m}^{3} /\right.$ year; Wikipedia $\left.2009 \mathrm{a}\right)$, only a little more than $2 \%$ of that required for irrigation of the Sahara Forest, as proposed above.

By comparison, both the ground- and surface-water-resources of Australia are more limited (e.g., its Great Artesian Basin contains about $8.7 \times 10^{12} \mathrm{~m}^{3}$ of water (Malkovic 2007)).

In the early 1980s, (Ornstein, Rind, Russell, Stone and Hansen, unpublished) ${ }^{2}$, used GISS Model II GCM, with $8^{\circ} \times 10^{\circ}$ resolution (Hansen et al. 1983), to model an irrigated, forested Sahara, with low albedo and increased surface roughness to 

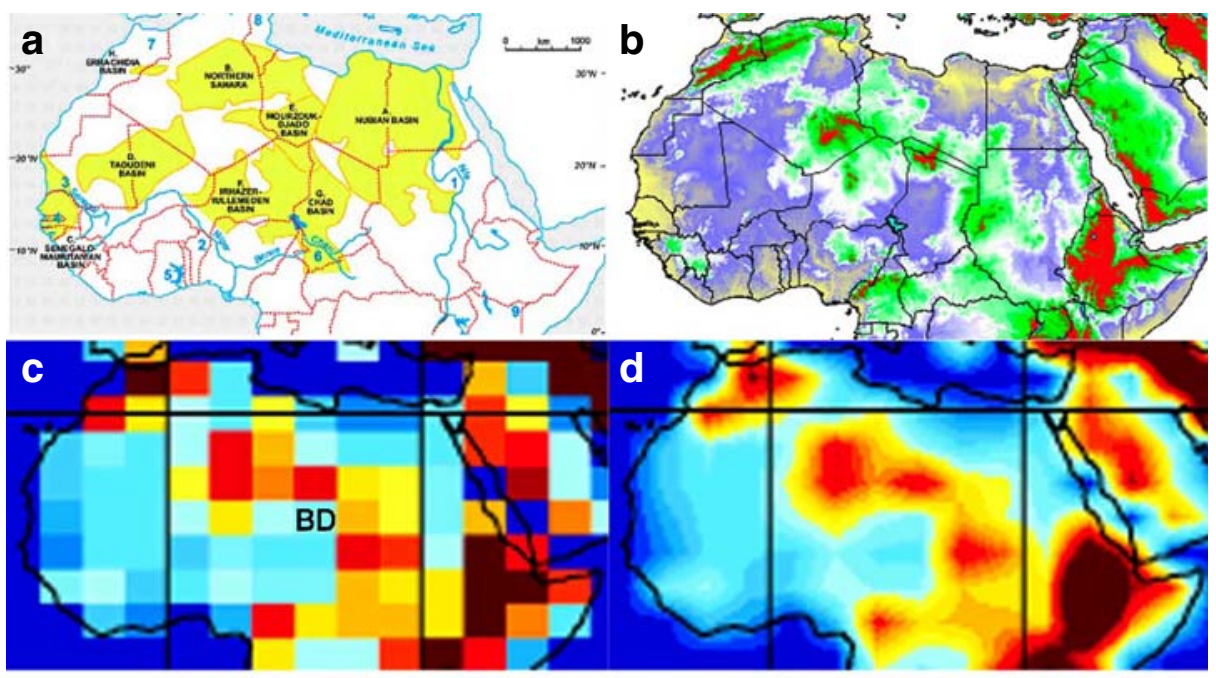

TOPOGRAPHY (METERS)

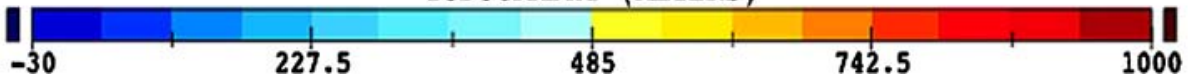

Fig. 2 a The distribution of fossil aquifers in northern Africa (Zuppi and Sacchi 2004). b A topographic map of northern Africa for comparison with c and d. c Raw $4^{\circ} \times 5^{\circ}$ representation of the topography, as used by GISS ModelE GCM. The cell which represents the Bodélé Depression is indicated as $B D$. d The same data as in c, but interpolated to give a better sense of how this level of model resolution represents 'truth'; i.e., b

explore the use of the Saharan fossil aquifers to prime a pump for Charney et al.'s (1975) biogeophysical positive feedback. If sufficient, biogeophysically-induced precipitation were distributed relatively uniformly during the year, irrigation might only be required during the early establishment of the forest. Having 'primed the pump', further irrigation (with unrenewable, fossil water) might no longer be required. But if the induced precipitation were seasonal, some irrigation would be needed 'forever'.

As only recently appreciated, 'irrigation' was poorly simulated by the computer code employed in that 1980s experiment; it added irrigation water only at the first time-step. That quickly dissipated, and resulting annual, weak increase in precipitation stimulated north of the Sahel, resulted only from albedo and roughness changes, and was insufficient to maintain the 'pump'-and no 'unlimited' supply of water was in the offing and the experiment was abandoned.

However, the cost of desalination of sea water, using reverse osmosis ( $\mathrm{RO}$ ), has very recently dropped to about $\$ 0.53$ per cubic meter of fresh water produced, (pumping/pressurizing, $1.58 \mathrm{kWh} / \mathrm{m}^{3}$, reported as half of the cost, and the rest for amortization and maintenance (Service 2006)). Construction of power stations in proximity to, or integrated with, desalination plants provides opportunities for delivery and production savings. And 'waste' heat might be used to separate sodium chloride and most magnesium and calcium sulfate $(\approx 90 \%$ of the desalination 'waste') 
to recover remaining marketable inorganics-some for selective addition back into the irrigation supply, as nutrients.

Powered by sunlight, Eucalyptus trees can sequester about $2 \mathrm{~kg}$ of carbon from about $7.33 \mathrm{~kg}$ of atmospheric $\mathrm{CO}_{2}$ for each cubic meter of water transpired (Stape et al. 2004a). Associated with such a broadleaf, evergreen tree, planted and irrigated on a sub-tropical desert, there are four major 'maintenance costs' and one 'one-time' construction cost to be considered:

(a) The ' $\mathrm{CO}_{2}$ footprint cost' is about equal to the $\mathrm{CO}_{2}$ footprint of the power sources used to desalinate and distribute the irrigation water needed to support it. The energy to pump water from sea level, to an elevation of about $450 \mathrm{~m}$ (the average elevation of the Sahara), with $50 \%$ hydraulic and electrical efficiency, is $2.46 \mathrm{kWh} / \mathrm{m}^{3}$. Our above estimate for the power consumed for RO desalination $\left(1.58 \mathrm{kWh} / \mathrm{m}^{3}\right)$ plus this additional amount for pumping for distribution totals $4.04 \mathrm{kWh} / \mathrm{m}^{3}$. The $\mathrm{CO}_{2}$ footprints of coal and natural gas (without Carbon Capture and Sequestration, CCS) and nuclear power are respectively about $0.7,0.4$ and $0.0033 \mathrm{~kg} \mathrm{CO}_{2}$ per kilowatt hour (Wikipedia 2009c). Thus, the total mitigation provided by irrigated afforestation might be diminished by $\mathrm{CO}_{2}$ footprints of about $38 \%$ with coal power, $22 \%$ with gas and $1.8 \%$ with nuclear power.

(b) The cost of electricity, at the power plant, varies from about $\$ 0.005$ to $\$ 1.60$ per kilowatt hour, (more typically $\$ 0.02$ to $\$ 0.06$ per kilowatt hour) depending upon the kind of power used (Wikipedia 2009d). This includes interest and amortization. Therefore, the $4.04 \mathrm{kWh} / \mathrm{m}^{3}$ (for sequestering $7.33 \mathrm{~kg} \mathrm{CO} 2$ in irrigated trees) varies from about $\$ 0.02$ to $\$ 6.50$ ( $\$ 2.73$ to $\$ 890$ per tonne of $\mathrm{CO}_{2}$ ). The value of the potentially-marketable carbon, sequestered by the trees, could reduce the net cost substantially.

(c) The costs of maintenance, interest and amortization of the desalination plants (about equal to the power costs), and of the aqueducts and irrigation systems (to be determined, but probably a small percentage of the power costs) must be added.

(d) The intangible costs of risks of possible leakage of stored $\mathrm{CCS}-\mathrm{CO}_{2}$; leakage of radioactive wastes; of nuclear proliferation; of air pollution; of accelerated deforestation; etc. must be considered.

(e) A one-time, $\mathrm{CO}_{2}$ footprint for construction of power plants, $\mathrm{RO}$ plants and aqueducts also must be taken into account, 'amortized' over the very long life of such structures.

To provide substantial mitigation, it will be desirable to power RO plants and pumping stations with low, or 'negative', $\mathrm{CO}_{2}$-footprint, electrical power plants: nuclear; coal-fired with CCS; sustainably-harvested wood-fired (e.g., Ornstein 2009), with or without CCS; hydropower; solar; wind; tidal; geothermal; etc. Which few types might entail the lowest dollar cost and lowest risks, at various locations along the coasts of North Africa and Australia, remains to be determined.

But generally, the larger the average biogeophysically-induced rainfall, the smaller will be all five costs-particularly the power costs. 
The $\mathrm{CO}_{2}$ from the burning of most oil, gas and gasoline enters the atmosphere from widely distributed, point emitters, incompatible with local capture. The price of a gallon of gasoline is a useful frame of reference for the current cost of energy. Because the supplies of oil are being depleted rapidly, that price now usually is increasing. A gallon of gasoline contains about $2.3 \mathrm{~kg}$ of carbon. Therefore, forest sequestration of the $\mathrm{CO}_{2}$, produced by the burning of a gallon of "gas", could cost as little as $\$ 0.61$ in desalination costs. With electric power at about $\$ 0.10$ per kilowatt hour, delivered, that raises the combined steady-state desalination and distribution pumping costs to about $\$ 0.87$ per gallon of "gas". ( $\$ 0.10$ per kilowatt hour is generous, if desalination plants and their power sources are built in proximity, as suggested above, since delivered costs for nuclear- and coal-generated electricity run between about $\$ 0.04$ and $\$ 0.06$ per kilowatt hour (Wikipedia 2009b; another way to look at it, using energy costs rather than 'dollar' costs: to produce and deliver $1 \mathrm{~m}^{3}$ of irrigation water to the Sahara therefore requires something like $14 \times 10^{6} \mathrm{~J}$.) Such an amount might be viewed as a new "tax" to be tacked on, at the pump, as the cost to recapture the $\mathrm{CO}_{2}$ produced as exhaust. (Note: since the energy to lift water increases almost linearly with elevation, the cost of pumping ground water exceeds that for desalination, as the depth of aquifers approaches 1,000 m.) An undetermined small amount, per $\mathrm{m}^{3}$ of water delivered, also must be added (at subsidized-as is often the case for 'agricultural' water-supply systems-or free-market prices). This would cover interest, amortization and maintenance costs for aqueduct and irrigation, distribution and pumping hardware, (with high conveyance and irrigation efficiencies (Howell 2003)).

To provide a somewhat different, economic perspective, we will examine costs from the frame of reference of the familiar 'barrel of crude'. A barrel of crude oil contains about $110 \mathrm{~kg}$ of carbon $(0.11 \mathrm{t} \mathrm{C}$ per barrel). The current cost of capturing approximately $90 \%$ of the $\mathrm{CO}_{2}$ from flue gas of yet-to-be-built, coal-fired, electric power plants, and pumping it underground, or under the ocean, (CCS), is between $\$ 100$ and $\$ 300$ per tonne C, (estimated by the Congressional Research Service; Folger $2007 ; \approx \$ 10$ to $\$ 30$ per barrel). This raises the effective cost of burning coal towards about half the 'present' price of oil. British estimates of CCS costs run about twice as high (Gough and Shackley 2005). On the other hand, forest sequestration of the carbon, produced by the burning of a barrel of crude oil, could cost as little as $\$ 30$ per barrel in desalination costs. Adding distribution pumping costs, that increases to about $\$ 43$ per barrel. But CCS $\mathrm{CO}_{2}$ is (hopefully) buried 'forever', and represents a total economic loss, whereas that captured by trees is mostly safe and useful, reduced carbon; a valuable product 'in the bank'. Effectively, this doubles the savings for photosynthetic sequestration relative to CCS; and it could capture an amount equal to $100 \%$ of all the $\mathrm{CO}_{2}$ currently released. This makes sub-tropical afforestation a more attractive 'solution' to warming. It adds a "tax" per unit $\mathrm{CO}_{2}$, comparable to, but probably less than the added CCS cost per unit $\mathrm{CO}_{2}$ from coal. And large-scale, RO-desalination and irrigation involve relatively mature technologies, whereas those of CCS are only beginning to be designed.

If the total volume of water required for irrigation can be reduced substantially, through biogeophysical-feedback-induced precipitation (Charney et al. 1975), the afforestation of subtropical deserts will gain additional economic advantage over CCS. Such possibilities will be explored next. 


\section{Modeling biogeophysical feedback}

We now appreciated that we needed better irrigation code than we used in the 1980s.

We use the GISS GCM ModelE, ${ }^{3}$ which provides $4^{\circ}$ latitude by $5^{\circ}$ longitude resolution (Schmidt et al. 2006). In the first of these irrigated rain forest experiments we replaced parts of the Sahara (yellow and orange areas in Fig. 1a) with an evergreen, tropical-rain-forest, vegetation type and also changed the corresponding desert soil to a composition typical for rain forests. [Fig. 2c, d illustrate the actual resolution of the model's topography and its interpolated representation (for a comparison Fig. 2b shows "real world" topography). Note: all model computations use the equivalent of the Fig. 2c representation-uninterpolated.] The 'land properties' were changed. Surface albedo was decreased to that of evergreen, tropical-rainforest vegetation with prescribed seasonal variation according to this vegetation type. Among other things, this defines the rate of evapotranspiration. The surface roughness was increased to match that of tropical rain forest; and the desert soil type was 'replaced' with the soil type for a rain forest 'cell'. ModelE employs a photosynthetic model as described by Friend and Kiang (2005), which allows us to compute gross primary productivity (GPP). At the start of the experiment the wetness of the "desert rain forest" soil was set to the value typical for a rain forest, close to saturation. At each time step (one half hour) the soil water content was checked, and if lower than this initial value, irrigation water was added under the trees to bring it back to a "rain forest" level (this is an equivalent to a "very highefficiency irrigation" regime).

Typically, the program is run for 20 years; 10 for spin-up, and 10 for data collection. Most run-outputs were for the decade, 1991-2000. 10-year monthly- or 10 -year-annual averages are illustrated. Raw output data are usually graphically interpolated. ${ }^{4}$

\footnotetext{
${ }^{3}$ For our experiments, we employ the Goddard Institute for Space Studies (GISS) ModelE General Circulation Model (GCM) which was documented in Schmidt et al. (2006) and had its sensitivity studied in Schmidt et al. (2006), Hansen et al. (2005). Its atmospheric part is a 20-layer version with model top at $0.1 \mathrm{hPa}$ and $4^{\circ} \times 5^{\circ}$ horizontal resolution. The land surface part employs a six-layer ground hydrology model (Rosenzweig and Abramopoulos 1997), a three-layer Snow model (LynchStieglitz 1994) and Friend and Kiang (2005) canopy conductance model. The Friend-Kiang model is physiology-based, and can compute Gross Primary Productivity (GPP) (which is of particular interest for our studies). GISS ModelE can run either with prescribed ocean (i.e. driven by observations), or it can be coupled to a dynamic ocean model. In the coupled version we employ the Russell et al. (1995) ocean model.

The land surface has a prescribed vegetation cover. The model distinguishes between eight types of vegetation and bare soil. For each vegetation type, its height and root distribution are fixed, while its albedo and leaf area index follow a prescribed seasonal cycle. The soil is a prescribed composition of five different soil textures.

The horizontal resolution of the model is rather coarse, but use of second-order moments for numerical differencing improves the effective resolution for the transport of tracers. For a convenience of representation most results of simulations shown in this paper are interpolated (see footnote 4).

${ }^{4}$ Most of the output of ModelE GCM has been processed with R. B. Schmunk's NASA Goddard Institute for Space Studies graphical output software, Panoply 2.2.1; http://www.giss. nasa.gov/tools/panoply/.
} 
Two separate models of the oceans are utilized:

1. A Fixed Ocean (FO), which uses interpolated, 10-year (1991-2000), monthly averages of the known sea surface temperatures (SSTs) and sea ice distributionthe same set, repeated each year. The FO model was run with fixed, preindustrial (1880) atmospheric, trace-gas forcings (the same each year). (With fixed, realistic SSTs, model results are not very sensitive to the known differences in atmospheric, trace-gas forcings from 1880 to 2000.)

2. Russell's Dynamic Coupled Ocean model (DCO; Russell et al. 1995), that includes atmosphere-to-ocean interactions which may locally or globally increase or decrease effects seen with the FO. The DCO model was run with historical atmospheric forcings (i.e., different each year).

The 1990s were characterized by four El Niño events; 1991 (strong), 1992 (moderate), 1994 (moderate), and 1997 (very strong) and one La Niña event, 1998 (strong); and this decade was also characterized as a 'warm phase' of the North Atlantic Oscillation during which the subtropical and tropical northern Atlantic averaged about $0.5^{\circ} \mathrm{C}$ warmer than average (Rodwell and Folland 2003; Kerr 2000; Null 2004).

So otherwise identical runs made with FO and DCO can be expected to show some differences which mainly relate both to atmosphere-to-ocean, interaction biases associated with the differences in their ocean representations and any inadequacies related to the nature of the approximations built into their designs. Figure 1b, illustrates the SST anomaly, when 10-year, annual averages of control DCO (computed 1991-2000 atmosphere and ocean) are subtracted from control FO (with fixed atmosphere and a fixed ocean with interpolated monthly SSTs, averaged from historical, 1991-2000 measurements). Despite the fact that the DCO is 'representing' years with especially strong El Niños, the anomaly records especially cool SSTs off the coast of Peru, (a 'ghost' of the El Niños in the 10-year FO-average of the historical record). [The DCO model produces a realistic thermohaline circulation, but yields unrealistically weak, El Niño-like, tropical variability as a result of its coarse resolution (see Fig. 17c, Hansen et al. 2005). But it can produce a semi-permanent El Niño as well as warmer-than-realistic temperatures in the northeastern Atlantic.] The northern, subtropical Atlantic also shows a pronounced warm anomaly (up to $4^{\circ} \mathrm{C}$ ); that is, DCO gives cooler SSTs there, than FO (the historical record). Therefore, simulated north African climate may show a significant positive bias with FO, relative to DCO, if SST in this Atlantic region plays a significant role in precipitation over northern Africa. These possible 'limitations' will enter into the interpretation of the results that will now be reviewed.

\subsection{First results}

Figure 3a (FO) and b (DCO) illustrate annual precipitation anomalies over the irrigated Sahara (SRF; differences from their respective 'normal' Sahara controls). Both show very substantial stimulation of precipitation over the Sahara; in FO, a minimum of about $700 \mathrm{~mm} /$ year, and well over 1,200 $\mathrm{mm} /$ year for about one half the Sahara; and for DCO, over 1,000 mm/year for about one half of the Sahara. The eastern irrigated Sahara receives considerably more precipitation in FO than DCO. The effects of afforestation and irrigation are decidedly local; and except for a desirable increase in rainfall over the Sahel to the south, there is very little 

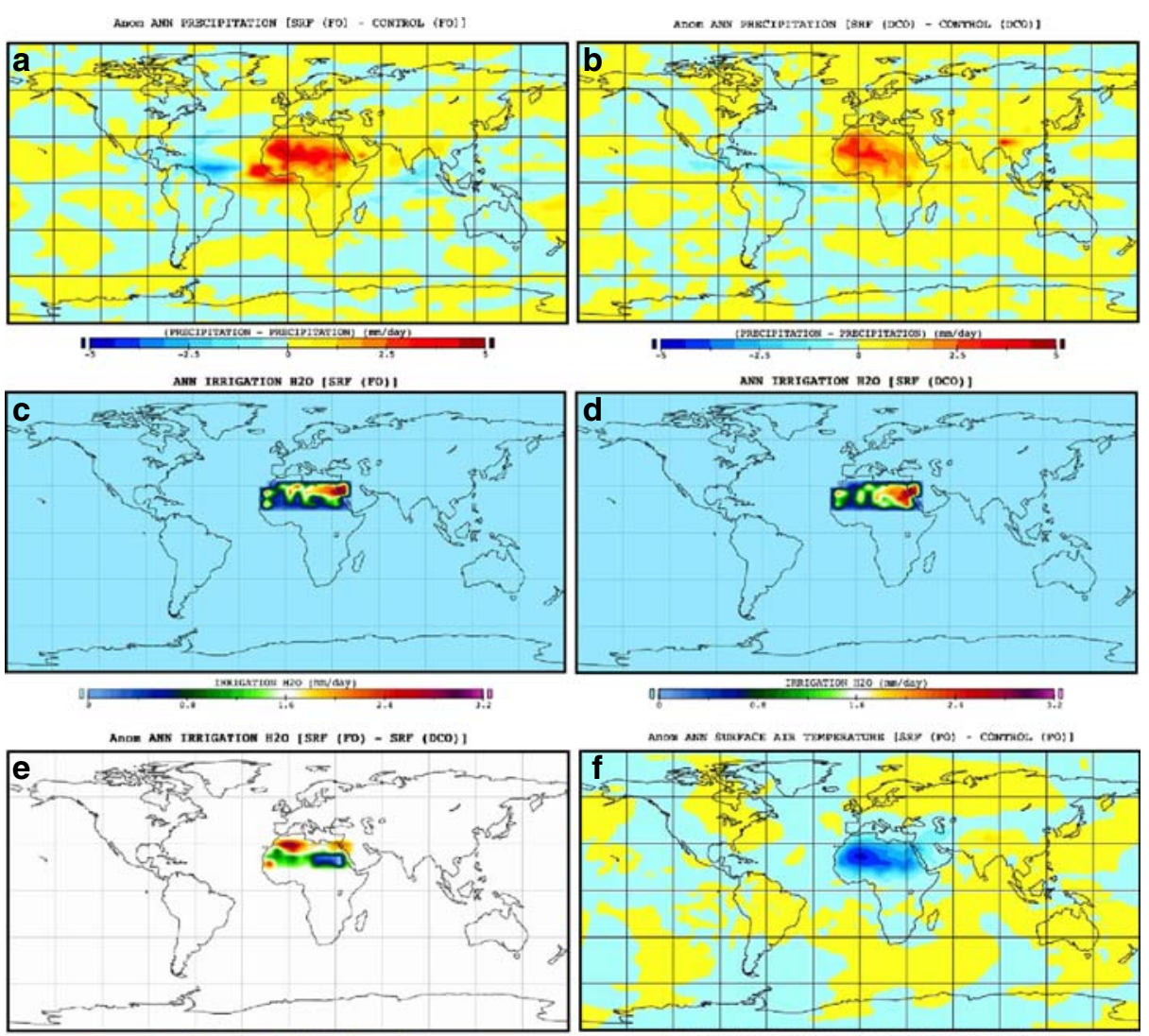

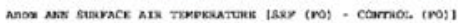

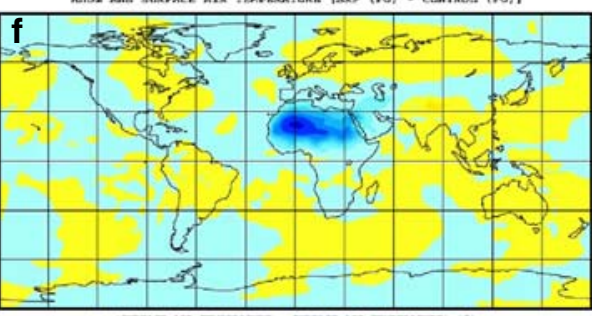

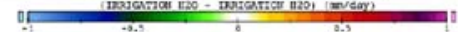

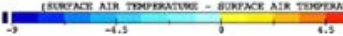

Fig. 3 All 10-year annual averages (ANN). a, b, e, f Differences between of SRF and CONTROL. a, b Precipitation, in millimeter per day; a fixed ocean; b dynamic couple ocean. c, d Annual SRF irrigation, in millimeter per day; $\mathbf{c}$ fixed ocean; $\mathbf{d}$ dynamic coupled ocean. e Difference between $\mathbf{c}$ and d. $\mathbf{f}$ Difference in surface air temperatures, in degree Celsius, for fixed ocean

modification of rainfall, over land, outside of the Sahara. The amount of precipitation is substantial, relative to the 'requirement' of something like $1,000 \mathrm{~mm} /$ year rain for vigorous Eucalyptus growth. QuickTime files, SRF(FO).mov and SRF(DCO).mov (Ornstein et al. 2009) provide 12 month animations of the FO and DCO precipitation anomalies. The rainfall is shown, in both cases, to be highly seasonal; beginning in April, and ending in November, with a time and intensity profile very similar to that of a typical West African Monsoon (WAM; Lebel et al. 2005). Figure 3c and d show the annual required irrigation with $\mathrm{FO}$ and $\mathrm{DCO}$; automatically compensating for the available rainwater. In FO, the required irrigation for the western and southern Sahara has been reduced to the order of $300 \mathrm{~mm} /$ year, with substantial gains (over DCO) in the southeastern Sahara. The 'arc' of mountains, the Ahaggar, Tibetsi, Ennedi and Jabal Marrah (captured in ModelE's topography, Fig. 2c, d) play a role, in the WAM mechanism (Drobinski et al. 2005), and apparently in the distribution of the induced precipitation. Figure $3 e$ shows the difference, in required irrigation, between FO and DCO. Since the induced precipitation is all seasonal rain, an 
additional run was performed with irrigation applied only during the months from May to October.

The resulting precipitation (not illustrated) was virtually identical to that for the full-year irrigation, with much heavier irrigation required in May to refill the driedout, soil profiles, but with slightly reduced total required annual irrigation.

So an irrigated Sahara forest may be climatologically possible; the induced precipitation may be substantial and thus reduce irrigation costs favorably, compared to $\mathrm{CCS}$ costs. In addition to sequestering $\mathrm{CO}_{2}$, the irrigated forest also causes pronounced local decrease in surface temperature over the Sahara (e.g., Figs. $3 f$ and 5e). Evapotranspiration converts large amounts of sensible heat into latent heat. Although, from a global, net energy point of view, the conversion of sensible to latent heat is a 'wash', induced cloudiness over the forest (e.g., Fig. 8a) keeps planetary albedo high (not illustrated) and further reduces surface heating. As a result no additional global warming was observed in our simulations, in contrast to what might be expected of afforestation at higher latitudes (Bala et al. 2007).

Can the irrigation requirements (fixed capital investment and/or operating costs) be further reduced without significantly reducing feedback rainfall?

Our ability to answer that question may depend on our understanding of the climatic mechanisms that have produced this initial result.

\subsection{Local mechanisms associated with Saharan rainfall}

Perhaps the most valuable clue is the similarity of the induced precipitation event to the ordinary WAM. Important parameters in the highly variable northward penetration of the WAM have been noted (Gu and Adler 2004; Matthews 2004). In the summer months, surface westerlies develop over the Atlantic, near the western and southwestern coasts of northwest Africa, picking up moisture from the warm, northern, equatorial and subtropical Atlantic, and advecting it in over the coast. During the summer, the African Easterly Jet (AEJ) develops at a latitude of about $15^{\circ} \mathrm{N}$, at about $600 \mathrm{mb}$, tending to steer the northward penetrating WAM back towards the Atlantic. The Tropical Easterly Jet (TEJ) is found centered at about $170 \mathrm{mb}$. The strengths and locations of these winds seem to be important to the WAM (Nicholson 1981, 2006). Kerry Cook (1999) established that the AEJ arises because of the strong contrast between the hot, dry, summer low over the Sahara and the cooler, moist, equatorial, air mass to its south. With a meso-scale climate model, she demonstrated that if the Sahara soil is kept moist during the summer, the AEJ fails to form. Figure $4 \mathrm{a}$ and d illustrate that the surface westerlies, the AEJ and the TEJ are well simulated in August (the peak of the WAM) in an FO, control-model run (normal Sahara). Figure $4 \mathrm{~b}$ and e show that with irrigation and forest, the AEJ has disappeared and the TEJ has strengthened and its northern edge has moved from about $15^{\circ} \mathrm{N}$ to about $22^{\circ} \mathrm{N}$. Figure $4 \mathrm{c}$ and $\mathrm{f}$ show the differences between the FO run with, and without, irrigated forest. 'Blue' differences show clearly that virtually the only large, global change in E-W winds at $630 \mathrm{mb}$ is that the AEJ has been 'wiped out' by the irrigated forest. The story is almost identical for the DCO runs (not illustrated).

There have been numerous studies of variability and of modeled movements of the WAM, both recent (Vizy and Cook 2001; Nicholson 1993; Janicot 1992; Druyan 1991) and historic (e.g., during the Holocene wet period). The historical 

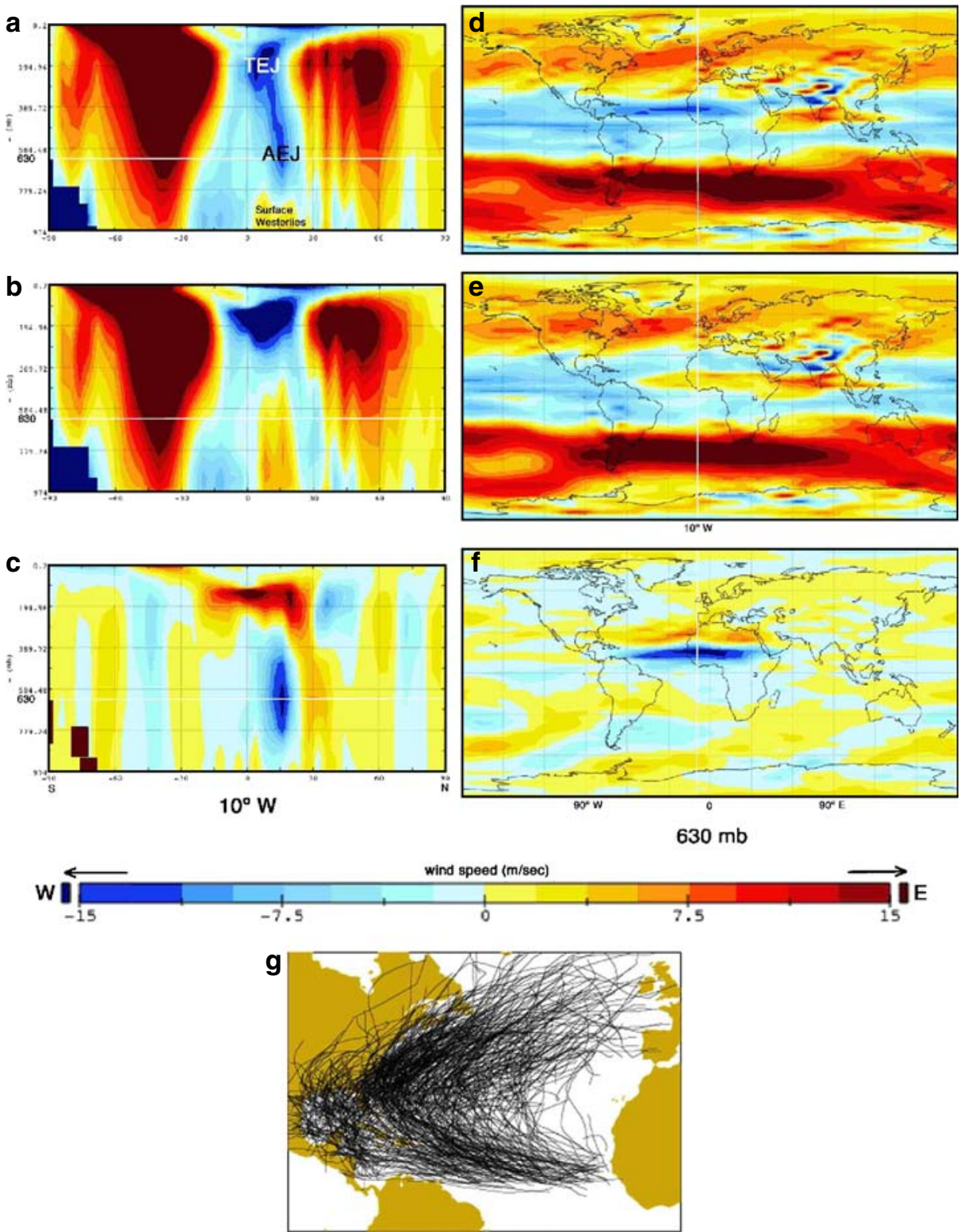

Hurricane Tracks

Fig. 4 a-f Ten-year August averages of SRF East-West component of wind speeds, in meter per second; fixed ocean (FO). a-c Air pressure, in mb ('elevation'), versus latitude at $10^{\circ} \mathrm{W}$ longitude; indicated by a vertical white line in d-f. d-f Latitude versus longitude, at $630 \mathrm{mb}$ pressure; indicated by horizontal white lines in $\mathbf{a}$ and $\mathbf{b}$. a, $\mathbf{d}$ Control winds. b, $\mathbf{f}$ Winds with irrigated Sahara forest (SRF). c Difference between $\mathbf{a}$ and $\mathbf{b}$. f Difference between $\mathbf{d}$ and $\mathbf{e}$. $\mathbf{g}$ Historic Atlantic hurricane tracks (Hall and Jewson 2005). Note that many of these tracks overlap the location, in $\mathbf{d}$ and $\mathbf{f}$, of the AEJ

forcing is presumably solar (Milankovitch) precessional forcing, followed by glacial melting and accelerated by subsequent greenhouse gas release (Braconnot et al. 1999; Kutzbach and Liu 1997). During 8,500-5,300 B.C.E., the Sahel savannah and 
grasslands extended almost to $30^{\circ} \mathrm{N}$, except over Egypt (Kuper and Kropelin 2006), and considerable amounts of precipitation ended up in the Sahara aquifer basins (Fig. 2a). Claussen (1997) examined a low-resolution climate model of the world, with deserts replaced with forests, and showed modest increase in precipitation over the Sahara. With a regional, meso-scale model, Cook et al. (2003), have simulated the Holocene climate of northern Africa with solar, albedo, surface roughness, soil moisture, $\mathrm{CO}_{2}$ and SST forcings, alone, and in various combinations, and have induced' moderate increases in precipitation (Patricola and Cook 2007), comparable to that of the Holocene, but not as large, or as far west or north as that illustrated in Fig. 3a and b. Near-surface, specific humidity is enhanced above an optimally irrigated forest, making our surface-moisture-forcing considerably stronger than theirs.

\subsection{Australia}

Irrigated afforestation of a realistic portion of the Australian desert would provide somewhat less than the required sink for the annual increase in anthropogenic $\mathrm{CO}_{2}$. However, together with conservation practices, it could take us a long way. (And this would be true, even absent cost-reducing, induced rainfall.)

\subsection{Modeling an Australian Outback forest}

The same treatment, as used with the Sahara, was applied to the combined red and magenta areas in Fig. 1a, using FO.

Figure 5a shows that, on an annual basis, substantial rainfall was induced over the central desert region, but less than in the Sahara (note reduced scale in Fig. 5a). However, since the Outback normally receives $50-300 \mathrm{~mm} /$ year rainfall, the totals are not too different, and the required irrigation, Fig. 5b, is similar. So costs would be reduced in Australia, as well. World-wide, the annual effect seems to be largely local. But, 10-year, monthly averages (see QuickTime animation AuRF(FO).mov, Ornstein et al. 2009) show some weak teleconnections. And, small levels of anomalous rainfall occur over different regions of the Outback all year. However, the predominant rainfall occurs during the austral summer, in parallel with the Indonesian-Australian Summer Monsoon (I-ASM), and the austral, summer, control runs show an 'Australian Easterly Jet' (AusEJ), similar to, but less extensive than, the AEJ (see Fig. 6a). The AusEJ is eliminated in the forested, irrigated run (see Fig. 6b).

\subsection{Loose ends}

In the original DCO runs, but not in fixed ocean runs (FO = fixed SSTs), the difference between the SSTs of the irrigated Sahara and its control, shows a small $\left(\approx 1^{\circ} \mathrm{C}\right)$, year-round increase, just adjacent to the western coast of northwest Africa (see Fig. 7a). And this anomaly quickly developed during the first 6 months of spin-up. It was out of concern that a quirk in the DCO model might have been responsible for this warm spot and might have made an inordinate contribution to precipitation over the Sahara, that we then made FO runs. We concluded that, rather than anomalous transport of heat to the ocean, the rise in SSTs is probably due to an irrigated-forest-induced diminution of the component of the year-round, off-shore 

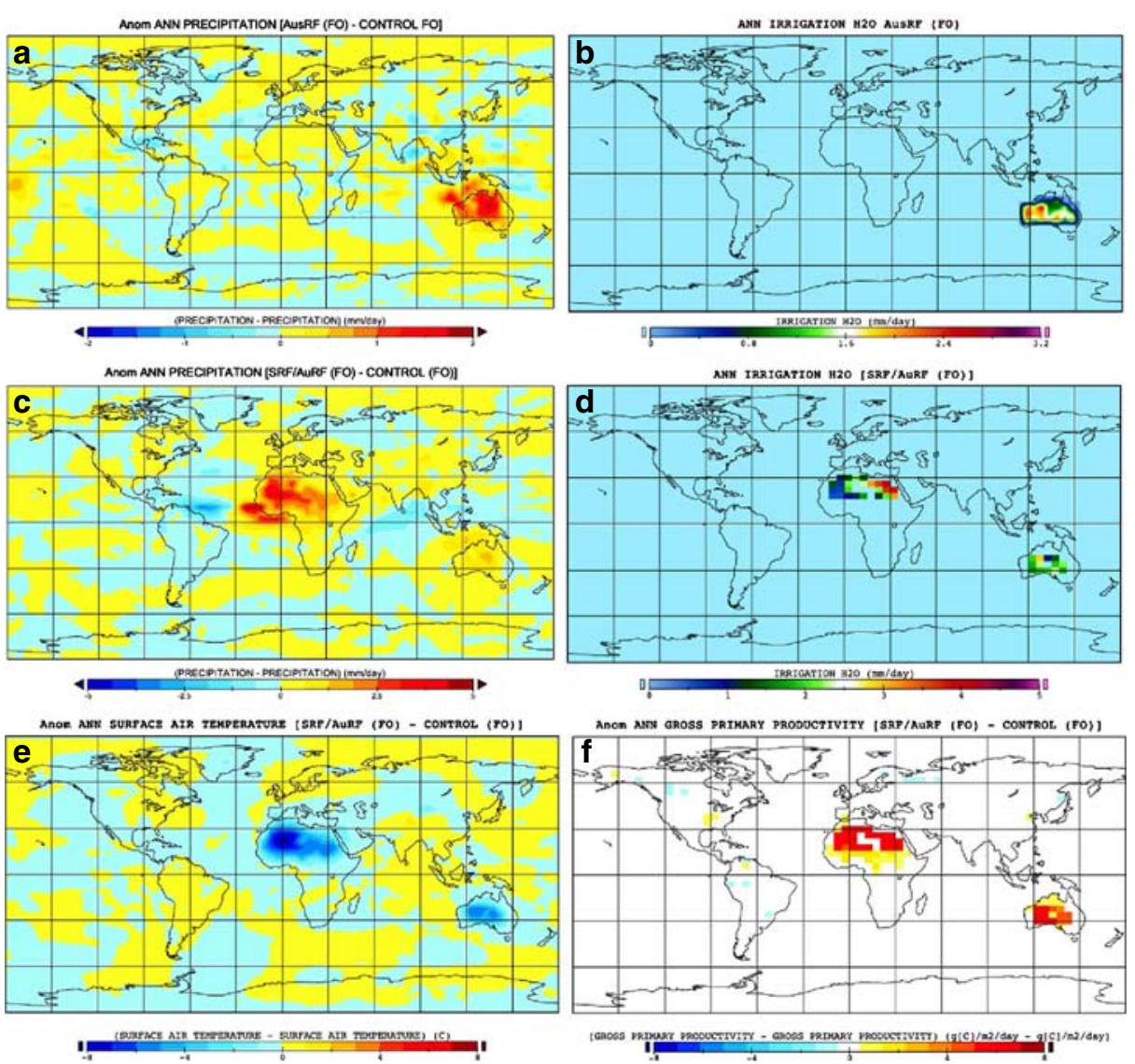

Fig. 5 All 10-year annual averages. a, b Australian Rain Forest runs with fixed ocean AuRF (FO). cf Combined reduced Sahara and reduced Australian Rain Forest runs with fixed ocean SRF/AuRF (FO). a Difference in precipitation, in millimeter per day, between AuRF (FO) and CONTROL (FO). (Note: the scale here is -2 to +2 , rather than -5 to +5 , as in c, e, Fig. $3 a$, b, to emphasize the weaker induced precipitation.) c Differences in precipitation, in millimeter per day, between SRF/AuRF (FO) and CONTROL (FO). b Irrigation, in millimeter per day, with AuRF (FO). d Irrigation, in millimeter per day, with SRF/AuRF (FO); raw data. e Difference in surface air temperatures, in degree Celsius, [SRF/AuRF (FO) minus CONTROL (FO)]. $\mathbf{f}$ Difference in Gross Primary Productivity (GPP), in gram per square meter per day, [SRF/Aurf (FO) minus CONTROL (FO)]

surface winds that blow steadily to the south (see Fig. 7b (FO); almost identical in DCO runs, not illustrated). The northeast, trade winds, that Columbus and his successors depended upon to take them to the New World, blow quite steadily to the south along this coast. These winds normally induce steady, Ekman-pump upwelling that cools the surface, coastal waters and fertilizes a very prolific fishery (Santos et al. 2005). This supports, not only local Mauritanian fisherman, but international fleets of fishing, factory ships. The near-shore component of these winds are supposedly enhanced by the sharp contrast between the hot desert coast and the cooler Atlantic (somewhat like the mechanism for the AEJ), that the forest eliminated. Perhaps by 
Fig. 6 The elimination of the "AusEJ." 10-year February averages of AuRF (FO) East-West component of wind speeds, in meter per second, at $630 \mathrm{mb}$; latitude versus longitude. a Control winds. b Winds with irrigated Australian forest

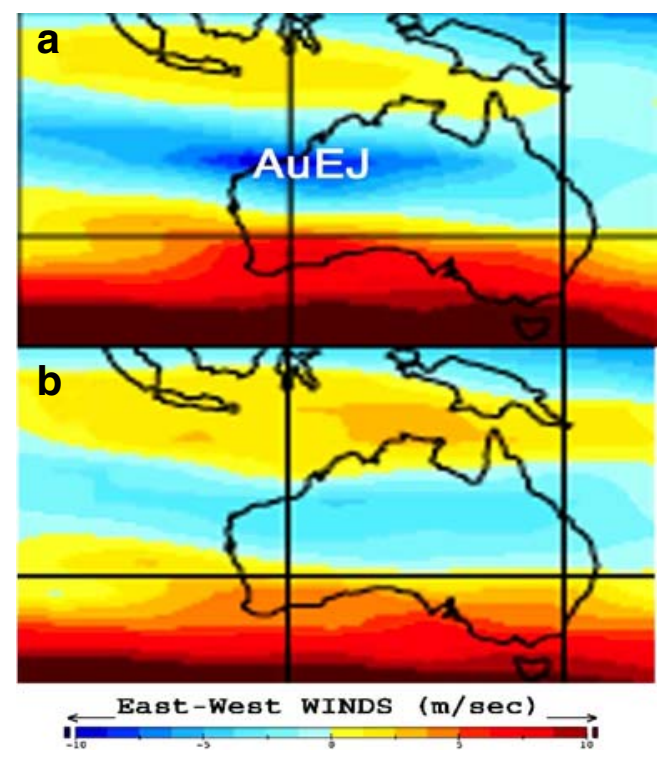

excluding the irrigated forest from a strip of that coastal region, the usual coastal wind pattern, and the consequent upwelling, might be preserved?

A desert area in Chad, the Bodélé Depression (the BD-marked, $4^{\circ} \times 5^{\circ}$ cell in Fig. 2c), located northeast of Lake Chad (Fig. 2b), is the almost exclusive source of iron-rich dust, from the residue of the Holocene 'Lake Mega Chad'. This dust is made airborne by the winter, Harmattan winds, that blow from the northeast over the Depression. And this dust ends up fertilizing the subtropical and tropical Atlantic, the Caribbean and the Amazon (Koren et al. 2006). Even if we avoided irrigating and afforestation of the BD cell, summer precipitation induced by the rest of the irrigated forest might wet this region sufficiently to terminate this mechanism. Perhaps we could test this hypothesis?

Therefore, we made two additional runs, with fixed ocean and dynamic coupled ocean, to try to resolve such loose ends. These used the orange and magenta regions, in Fig. 1, to represent the Sahara and Australian Outback, respectively. The Saharan desert forest is reduced to about $5.7 \times 10^{8}$ ha (that can still sequester 3.5 to $7 \mathrm{Gt} \mathrm{C}$ per year). Both irrigated forests were 'installed' for each run. The possible upwellingand BD-dust-preserving changes just discussed were implemented.

Fig. 7 All 10-year annual averages differences with dynamic coupled ocean (DCO). a Difference, in degree Celsius, in SSTs between (SRF and CONTROL). b Differences in surface wind speeds and directions, in meter per second, between (SRF/AuRF and CONTROL). c Difference, in degree Celsius, in SSTs between (SRF/AuRF and CONTROL) 


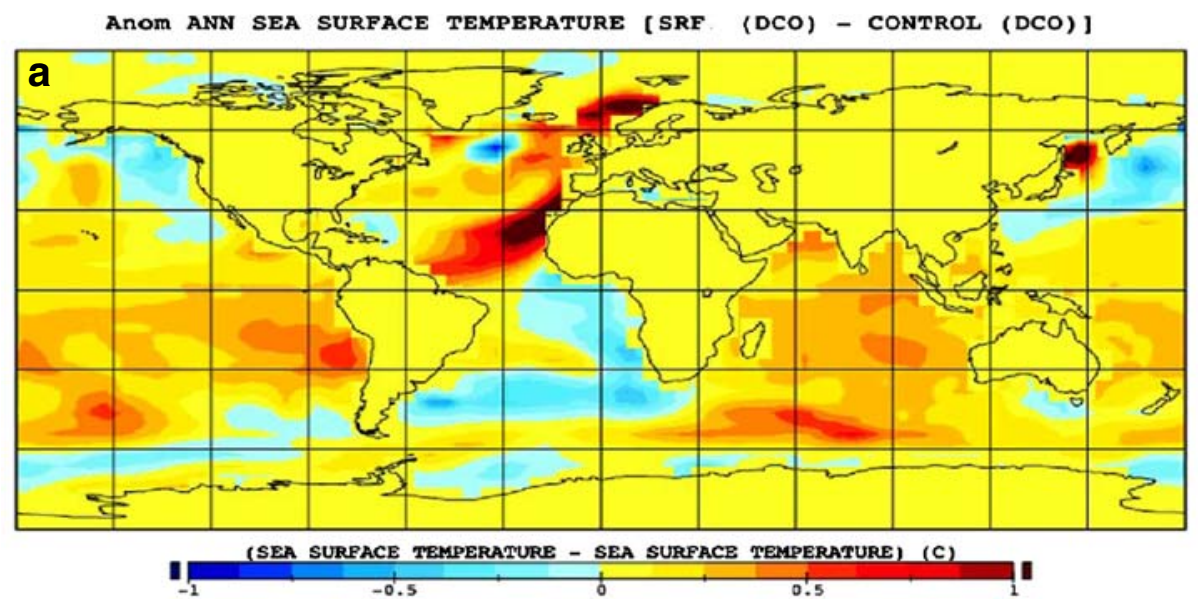

AnOM ANT SURFACE WIND [SRF (DCO) - CONTROL (DCO)]
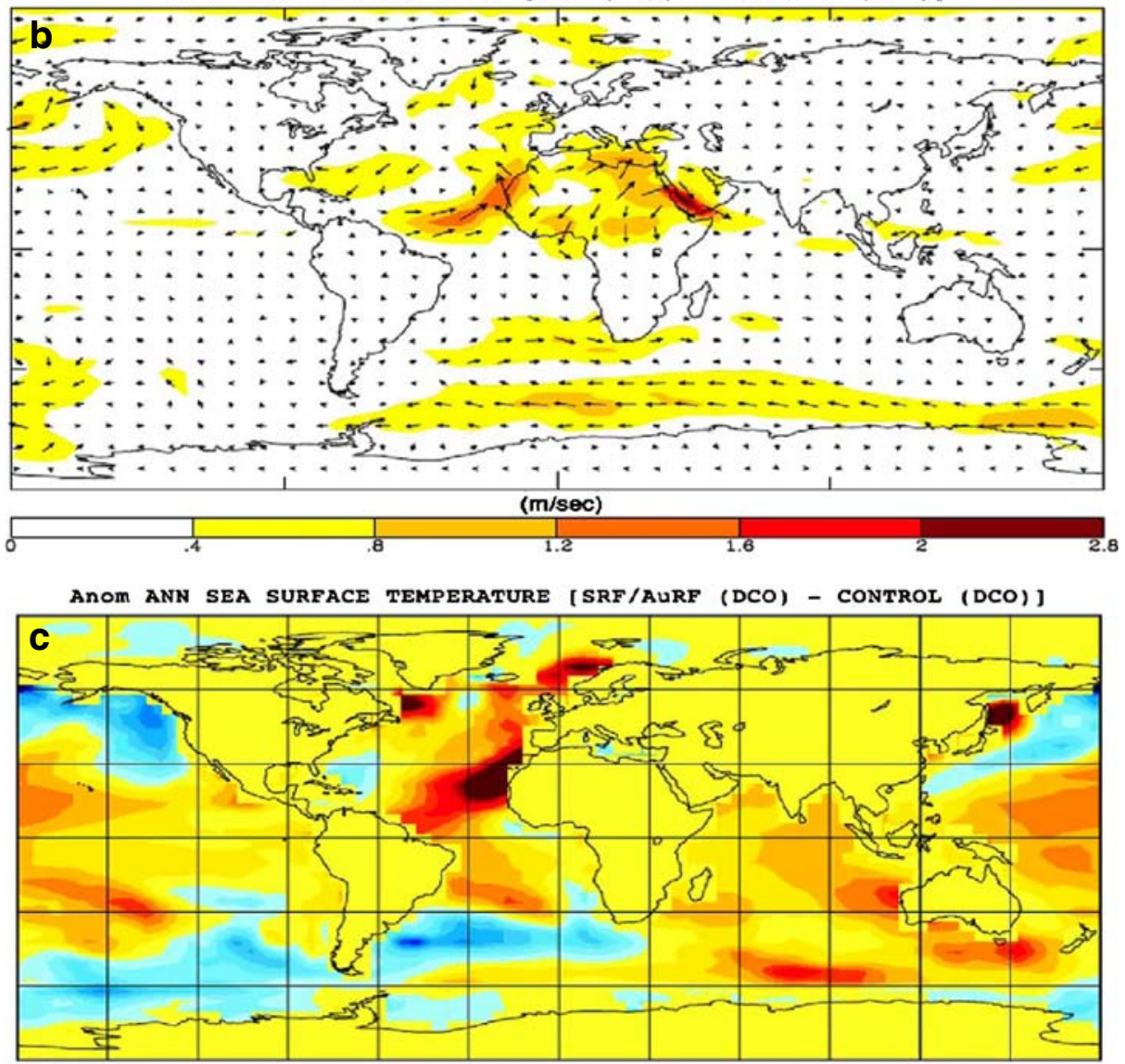

(SEA SURFACE TEMPERATURE - SEA SURFACE TEMPERATURE) (C)
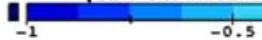

0.5 

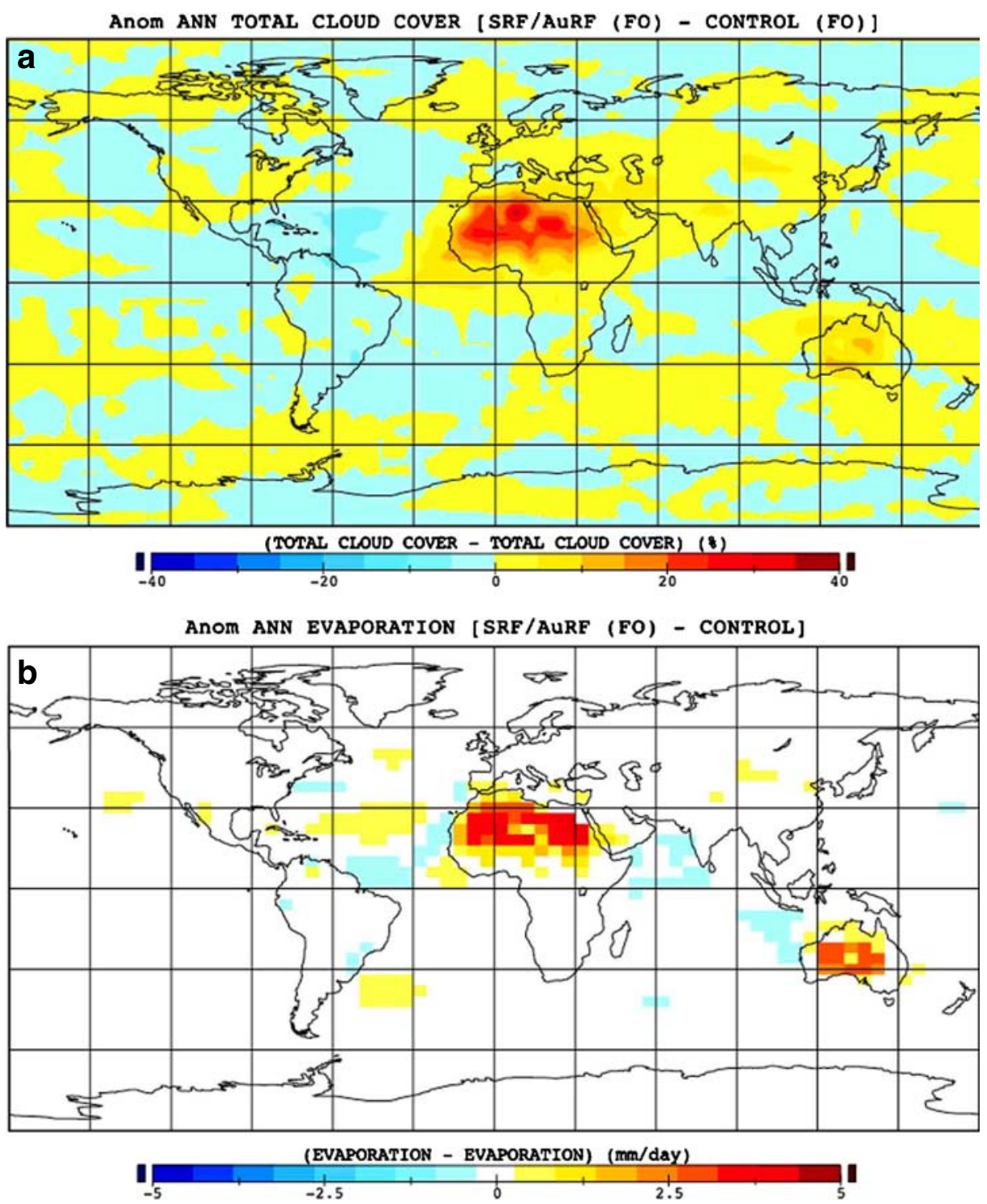

Fig. 8 Cloud cover and evaporation in SRF/AuRF. 10-year annual averages of SRF/AuRF (FO) differences from CONTROL (FO). a Total cloud cover, in percent. b Evaporation, in millimeter per day; raw output

And, (a) forest was not installed on other margins of the deserts, where competing uses might generate problems; (b) a few prominent mountain regions (four cells in the Sahara and one in Australia) were excluded, because afforestation and irrigation of mountain ranges would be excessively expensive and therefore makes little sense; and (c) forest was excluded from most of Egypt, which in our earlier irrigated runs, and during the Holocene wet period, received the least precipitation. 


\subsection{Supplementary results}

Figure 7c, with DCO, shows that even when the western coast is preserved as desert, the local SST anomaly of Fig. 7a is almost perfectly reproduced.

Apparently, the impact of an even somewhat reduced Saharan forest, through its still very large impact on its Hadley Cell circulation, also weakens the coastal northeast trade winds and impacts upwelling. (Fig. 7c also shows some smaller SSTchanges off the western and southern coasts of Australia.)

Figures 5 and 9 show that the unirrigated BD is nonetheless wet by about $500 \mathrm{~mm} /$ year of induced precipitation.

Other results with FO and DCO were very similar. Only FO results are illustrated.

Figure 5b and QuickTime animation SRF/AuRf(FO).mov (Ornstein et al. 2009) show that the reduction in the sizes of the two irrigated forests result in both diminished areas and magnitudes of the induced precipitation, and with a rather large, negative bias over Libya and Egypt. Figures 5e and 8a show that the latter bias is explained by the reduced cloudiness, and consequent increased surface temperatures over this part of the forest. The planetary albedo there drops almost to the value of the surface (forest) albedo (not illustrated). This results in increased evaporation (see Fig. 8b) and resulting irrigation demands rise there to about 1,600 mm/year (Fig. 5d).

The bottom line: the combined GPP for the reduced-sized Sahara and Australian irrigated forests, as calculated by (the currently, rather simple vegetation module of) ModelE, is illustrated in Fig. 5f. For a Eucalypt forest, this is multiplied by about 0.45
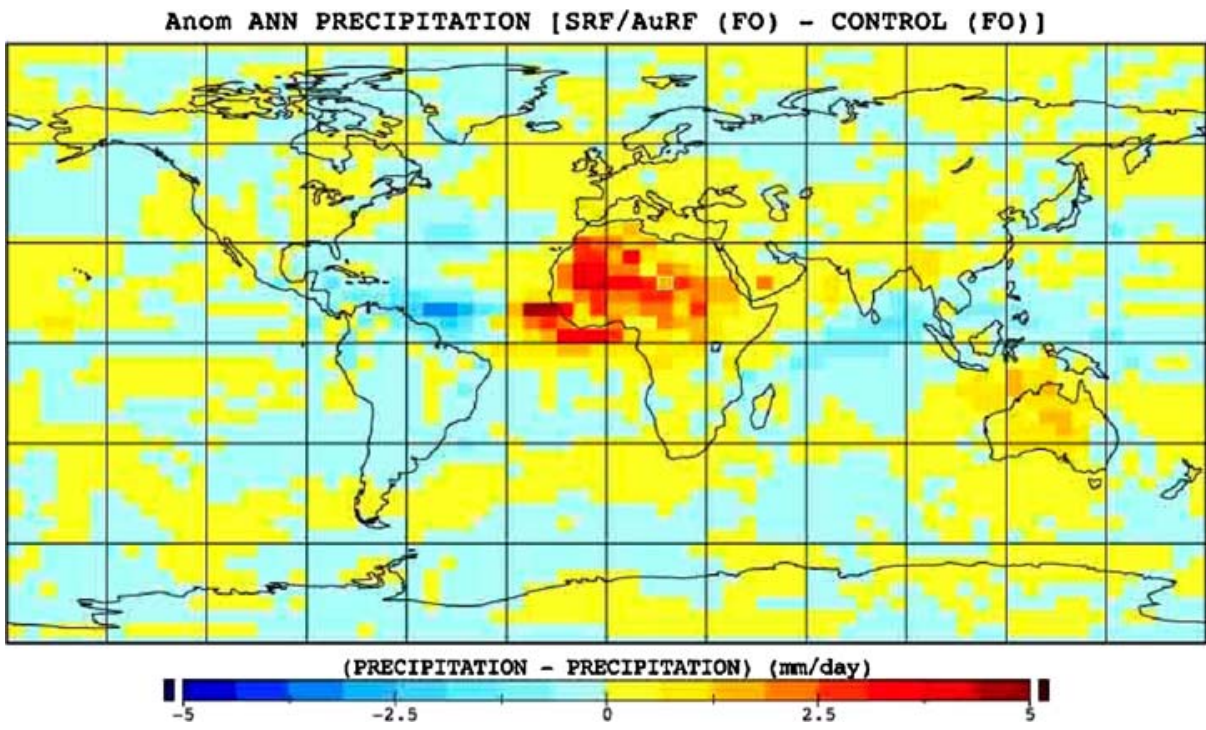

Fig. 9 Rainfall over the Bodélé Depression. Ten-year annual average of SRF/AuRF (FO) difference in precipitation, in millimeter per day, from CONTROL (FO); raw output. The cell which represents the Bodélé Depression is outlined in white and exhibits over $450 \mathrm{~mm} /$ year precipitation 
to get NPP (Stape et al. 2004b). And this comes to about $8 \mathrm{Gt} \mathrm{C}$ per year; close to the required sequestration capacity to deal with global warming. And there is a bonus of a slight increase in GPP for the Sahel and northern tropical Africa from the up to $700 \mathrm{~mm} /$ year of extra rainfall (Figs. 5c and 9).

\section{Mechanisms common to impacts of both Saharan and Australian afforestation/irrigation}

In Saharan and Australian runs, irrigated forests provide enough extra humidity to that advected in from the oceans by warm, moist winds, to induce deep convection and resulting local precipitation. Since Australia is surrounded by oceans, there are more occasions during the year when various winds may advect near-dewpoint masses of air in over its deserts. Additionally, elimination of the AEJ and AusEJ, and the northern displacement of the TEJ, may increase the coverage of the WAM and I-ASM monsoons by presently poorly understood mechanisms; permitting deeper northern penetration of such oceanic, moist-air masses in Africa, and deeper south, in Australia. The larger the local area irrigated and forested, the more extensive the induced precipitation. And the induced cloud-cover and surface cooling probably play a significant role in lowering the level of required irrigation somewhat independently of, and in addition to, the level of induced precipitation.

These mechanisms do not hint at any manipulations that might produce further substantial reductions in the costs of irrigation. It would appear that larger, rather than smaller areas of irrigated afforestation favor reduced operating costs per ha, but of course, increased capital costs.

\section{The Australian opportunity}

Australians are in a unique position. They have a democratic form of government, are well-educated and have a thriving economy. They will easily appreciate the unique opportunity they have to help control warming. With one third of the Carbon taxes collected from the rest of the developed world (two thirds might be set aside to cover conversion of the Sahara), and with support of the capital markets, they should be able to start construction of the necessary infrastructure and then begin planting and irrigating an Outback Forest with relative dispatch.

The required capacity in desalination and power infrastructure, that would normally be under-used during parts of the year, provide opportunities for substantial creative agricultural and industrial use, outside of the forest.

A working Australian example may help convince the populations and governments of Mauritania, Mali, Niger, Chad, Sudan, Algeria, Tunisia, and (Libya and Egypt?) that similar cooperation in controlling global warming is also in their own self interests. If such creative opportunities were seized by these African nations, it could permit accelerated transition from their status from "developing" to "developed", with rapid increase in standards of living. On a smaller scale, similar opportunities may be available through irrigated afforestation of parts of the Arabian peninsula and the Kalahari desert. 


\section{What might we find in this terraforming Pandora's box?}

Even though the main climatological sequelae seem quite 'local', in the examined scenarios, some obvious (and not so obvious) possible results need to be closely examined.

Global warming is an unanticipated, Malthusean consequence of "tampering with mother nature". We may anticipate other consequences that might follow from planting such enormous irrigated forests. In the spirit of the medical admonition, "First, do no harm," we review possible negative outcomes:

Extraordinary volumes of highly saline 'waste' water, from the desalination plants, will have to be diluted and safely diverted back to the ocean in ways which ensure that thermohaline circulations are not disturbed, and that hyper-saline, anoxic 'dead zones' are not created in ocean basins.

Capping warming should cap the world-wide, increasing intensity of tropical cyclones that is expected to be otherwise induced by rising SSTs (Willoughby 2007; Kerr 2006; Gopalakrishnan et al. 2002). But many Atlantic hurricanes originate in a region that matches the western portion of the AEJ (see Fig. 4g, (from Hall and Jewson 2005)), and the AEJ is selectively 'wiped out' by irrigation of the Sahara (see Fig. 4a-f). The AEJ

... forms and blows essentially through the monsoon season, and it is disturbances on that jet that move into the Atlantic... Perhaps half of the major hurricanes that hit the United States have their origin in those disturbances (Zipser 2006, also see Cifelli et al. 2007).

Will the Caribbean, Gulf of Mexico and US be better off, or worse off, after the forest is installed on the Sahara? Also, it has been suggested that summer, Saharan dust suppresses hurricanes (see Kerr 2007). Most summer, Saharan sources of dust will definitely be eliminated. Can that consequence be tolerated?

In connection with an Australian forest, teleconnections, and the 'wiping out' of the AusEJ, in a region so sensitive to, and intimately connected to the western end of the ENSO (El Niño Southern Oscillation; Lau and Bua 2004; Lau and Yang 1996; Allen 1983), need to be explored with care. In Fig. 7a, the Pacific looks like its in an El Niño state; in Fig. 7c, more like a La Niña state, suggesting a significant impact on ENSO.

During the cool, nearly precipitation-free third of the year, the Sahara forest would be quite dry, even with irrigation (see SRF(FO).mov, SRF(DCO).mov and SRF/AuRF(FO).mov, Ornstein et al. 2009). It may be important to select droughtresistant clones of Eucalypts with low nighttime and winter transpiration rates (Benyon 1999), especially if irrigation is to be reduced during the winter. Ground litter will be very dry. Whether planted with broadleaf evergreens, like Eucalypt species, or with deciduous, water conserving trees, like Baobabs, or mixtures of appropriate species (to avoid the hazards of monoculture (Cannell 1999; Powers 1999)), such forests will be at considerable winter risk of destruction by fire. They will have to be planted with strategically located firebreaks and fire stations to protect these enormous investments and climate engines.

It may be possible to optimize locations and schedules for irrigation to provide the most stable control of the nonlinear AEJ. However, since the WAM is notoriously fickle, 'bad years' must be anticipated due to other, uncontrolled variables. And it 
may be necessary to overdesign the irrigation system capacity to enable intervention during exceptional dry spells. Otherwise, substantial parts of a forest might die during such droughts, and turn off the biological, $\mathrm{CO}_{2}$ 'sequestration-pump'. Historically, such droughts (and fire) are presumed to have led to the demise of forests that previously occupied extensive parts of the present deserts of Africa and of Australia (Bradstock et al. 2002).

Africa, from Mauritania to Egypt, has been the home of the plague locust. Swarms are often stimulated by increases in precipitation. This may require a new level of 'insecticidal' preparedness.

Desert sands and soils are depleted of soluble nitrogen. As a result, it will probably be necessary to preplant, or interplant with nitrogen-fixing legumes (Forrester et al. 2006), such as fast-growing Acacia species. In order to learn how to transition local, arid micro-environments into moist, evergreen tropical-forest macro-environments, it may be necessary to conduct some preliminary field-trials of various mixes of tree species and of 'establishment strategies' on a variety of desert 'soils" (using fossil aquifers and perhaps wind or solar power to pump the irrigation water). Some analysis with dynamic vegetation GCMs (e.g., Kiang et al. 2007) may be helpful in this connection. This might delay the date at which the forest reaches a break-even

\footnotetext{
${ }^{5}$ The keys to initiating forest growth on desert soils

With present insolation, the poleward, then descending, atmospheric circulation of Hadley-cells desiccate the Sahara, the Australian Outback and subtropical deserts in general. Low levels of rainfall are responsible for their striking failure to support plant growth. There is no evidence that Sahara or Australian Outback mineralogy, with respect to average composition, is different than that of Amazonia or the Congo Basin, which support lush old-growth forests.

The textures of desert soils range from that of coarse sand to the very fine structure of deposits of clay. The water-holding capacity of sand is very low; only the narrowest capillary spaces between grains of sand oppose gravitational forces, as water rapidly percolates downward. On the other hand, a much larger proportion of the volume of clay is made up of microscopic capillary spaces, providing substantial water-holding capacity. Counterbalancing this advantage, water rapidly applied to a clay surface, tends to run off the surface much faster than it penetrates because viscous flow into small capillary spaces is slow. Water rapidly applied to a coarse sand surface usually penetrates quickly, down to roots-and then below. This summarizes two of the most important dimensions of soil variability that impact a soil's suitability for sustaining plant growth in natural, variable, nearlychaotic, rainfall regimes. No desert-wide, mineral deficiencies of potassium, phosphate and traceelements, differentiate deserts from other regions which support lush growth.

Therefore, when high-efficiency irrigation is used to apply water to root zones at slow rates that just replace losses due to local evapotranspiration, the suitability of a very wide range of soils is both equalized and maximized.

Accumulation of above-ground litterfall and root litter, and conversion, by soil microorganisms, fungi and invertebrates, into fibrous, hydrophilic humus, also improves, and tends to further increase and equalize, water-holding capacity and more rapid water-penetration of most types of soils. In addition to plants with symbiotic, nitrogen-fixing, root nodules (e.g., legumes), some non-symbiotic microorganisms provide nitrogen-fixation (Murder 1975). Those microorganisms, and traces of nitrate in rainfall, are the source of most forest, nutrient nitrogen. And mycorrhiza somewhat increase accessibility of inorganic nutrients, particularly phosphates.

Therefore, afforestation of most of a desert should require 'little more than' carefully-controlled irrigation-although in the forest's first years, until ecologically stable rhizospheres begin to form in the tree root zones, some auxiliary fertilization and microbial seeding should help. An irrigation system that can deliver $500 \mathrm{~mm} /$ year can be used to maintain a high relative humidity, with fogger/mister drip line emitters and/or seedling shelters around 'seedlings' (which themselves initially have very small photosynthetic transpiration demands). Preplanting and/or interplanting with tree species better adapted to the initial aridity than Eucalyptus grandis, may also help to transition and shelter from the arid environment, dominated by evaporation, to a humid macro-environment, dominated
} 
state, perhaps past a "tipping point," a point beyond which some very high costs of runaway, positive feedback cannot be controlled immediately (Lindsay and Zhang 2005).

The capital costs of the forests will exceed the revenues from any reasonable carbon tax and traded carbon credits. And in the Sahara, the necessary foreign capital-windfall would be spread across eight to nine underdeveloped nations. The political distribution will be difficult. Even for an Australian forest, the conflicts between concerned interests (indigenous residents, ranchers, farmers, conservationists, foreign investors, etc.) may be substantial.

\section{Conclusion}

Such multi-trillion-dollar projects provide lots of motivation for scientificallycreative entrepreneurs - as well as for swindlers. International mechanisms for monitoring and managing (without mangling or strangling) such projects will be essential. This may be the most difficult hurdle.

Our DCO model showed a cool bias in the Atlantic (Fig. 1b). It would be helpful to confirm these studies with other GCMs that do credible jobs at simulating both coupled oceans as well as monsoons (e.g., Cook and Vizy 2006), and particularly with higher resolution meso-scale models. The latter may better simulate the squalls that are typical of WAM precipitation (Duryan et al. 2004), and therefore should yield more confident estimates of stimulated rainfall and its distribution. However, GISS Model E underestimates both Amazonian precipitation (Schmidt et al. 2006) and the strength of monsoons (Rind et al. 2007). We have some concern that this may stem from the uncertain vertical convective parameterizations, shared by all GCMs. This could result in overestimation of the temperatures in the upper tropical troposphere, and as a consequence, an underestimate of deep convection and precipitation by most other GCMs, as well. ${ }^{6}$ As already noted, increased confidence in estimates of

by transpiration. In a few years, that transition also benefits from the positive-biogeophysicalfeedback precipitation of the enhanced WAM that we demonstrate in this study.

${ }^{6}$ Figures $9.1 \mathrm{c}$ and $9.1 \mathrm{f}$ of Chapter 9 of the report to the IPCC's AR-4, a study of GCM hindcasts (Hegerl et al. 2007), illustrate a rather uniform warming of about $1^{\circ} \mathrm{C}$ in the upper tropical troposphere ( 400 to $150 \mathrm{hPa}, 30^{\circ} \mathrm{N}$ to $\left.30^{\circ} \mathrm{S}\right)$ for the twentieth century, but only about $0.5^{\circ} \mathrm{C}$ per century increase at the surface. They state, "The major features shown in Fig. 9.1 are robust to using different climate models". Figure 6 in Santer et al. (2008) also shows a mean of 19 different GCMs (including ModelE), supporting an upper tropical troposphere warming of about $1{ }^{\circ} \mathrm{C}$ per century, and about $0.5^{\circ} \mathrm{C}$ per century at the surface.

Whether the tropical upper troposphere has warmed about twice as much as the surface, should be resolvable by examining historical measurements. Satellite measurements lack sufficient vertical resolution in the troposphere to settle this issue. Radiosonde environmental lapse-rate measurements have adequate vertical resolution and might provide a useful test. Radiosonde data (also in Fig. 6, Santer et al. 2008) seem to falsify these GCM hindcasts, but the geographical radiosonde samplings in the tropics are few and far between and a bias of direct solar-heating of sensors may also be involved. The warmer upper tropical troposphere of the GCMs implies convective stability that is somewhat greater, compared to that expected from the (limited) radiosonde data. Therefore until the question is resolved, of whether the modeling of the dynamics of tropical vertical heat transfer by GCMs is faulty, or alternatively that the sparse radiosonde data is unrepresentative or in error (Titchner et al. 2009), there will be concern that most GCMs, even if they confirm our results, may also tend to underestimate the precipitation induced by irrigated afforestation of Hadley Cell deserts. 
induced precipitation would be especially helpful, because the larger the induced rainfall, the smaller will be both the final average carbon footprint and the cost of maintenance of such afforestation projects.

Anthes (1984) demonstrated "Enhancement of convective precipitation by mesoscale variations in vegetative covering in semiarid regions". A patterned planting of the forests could be explored, at mesoscale, to determine whether precipitation might be further enhanced; perhaps during the winter dry seasons, ultimately making the forests sustainable, without irrigation. Meso-scale modeling also would permit restriction of irrigated afforestation fairly precisely (and more realistically) to elevations less than about $800 \mathrm{~m}$.

Many of the threatening scenarios, just reviewed, should be subject to extensive analysis.

And with refined calculations, costs may be lower-or higher.

Bias against consideration of afforestation, even as a possible solution, will be strong because of the common "scientific reticence" and "behavioral discounting" with respect to delayed bonuses. Such discounting tends to dominate analyses of risks and rewards that are perceived to be far off (Hansen 2007; Hariri et al. 2006; Axtell and McRae 2006). At the very least, such reticence must be repressed sufficiently to permit a balanced evaluation of the full spectrum of cures for the Earth's, anthropogenically-induced and mounting fever.

We must bite the bullet. Global warming will not go away by itself. A rapid approach towards zero-population-growth is required (Ornstein 1967; Anthes 1993). Existing forests must be conserved. Incremental increases in energy-use efficiencies are a sine qua non for improvement. However it is unlikely that energy conservation can provide the complete solution.

A replacement of present fossil-fuel, electric-power-generation plants with nuclear power generation, (with much stricter control of fissionable isotopes and radioactive waste) and/or with coal-fired plants with CCS, also can be managed incrementally, but at very large capital costs (and additional operating costs, for CCS). Solar, geothermal and wind power can make modest contributions. All of these are other parts of a fix. But the quicker a forest can be grown, the more time will be available to choose among, and to implement such adjustments - and perhaps to develop more attractive substitutes (e.g., working fusion power plants).

Our observations have slightly simplified the problem. Afforestation of subtropical deserts can reduce increases in atmospheric $\mathrm{CO}_{2}$, incrementally, and enormously. However, it can begin to show an operating-cost bonus (over CCS operating costs) of biogeophysically-induced rainfall, only after monumental capital investment in a major portion of the required desalination, power and irrigation infrastructure.

These capital costs of mitigation will be borne mainly by the citizens of the developed world. They must be weighed, not only against those of CCS, but as a kind of preemptive disaster relief - or repair of the 'commons' - to avoid the future, and as yet not easily estimated costs of vast coastal inundations, desertification of crop- and range-lands, drying up of water supplies; more intense tropical storms; the acidification of the oceans and loss of biodiversity. The integrated costs of coping with such changes could approach those of recovery following an asteroid impact or a nuclear war.

These are ecumenical, ethical, altruistic issues. How we deal with them depends upon how much value ordinary people (not economists or politicians) place on the 
welfare of their descendants; self versus children, grand-children, etc. The results of economic and policy calculations are meaningless unless we agree upon the magnitude to assign to this value (Hopkins 2007; Nordhaus 2007; Stern and Taylor 2007). Future generations ought not be 'discounted'.

Conservation, through increased efficiency, contributes to a "win-win" situation; reducing $\mathrm{CO}_{2}$ emissions and producing economic savings (e.g., "more miles per gallon of gas"). If automobile manufactures delivered a $\mathrm{CAFE}^{7}$ increase from the present standard of 27.5 miles/gallon to a value of 35 miles/gallon by 2020, as called for in the 2007 Energy Act H.R.6, passed on December 18, 2007, 8 an "afforestation tax" of about one third of the pump price of gasoline, would just be 'canceled'. There would be little pain, for an average driver, especially if technology more innovative than vehicle-weight reduction is used (Thompson 2007). Adjusted for inflation, about the same price per mile would be paid for gasoline, as today. (This is calculated without including additional savings resulting from biogeophysicallyinduced rainfall or from the marketing of renewable forest biomass.) And energy conservation of other kinds also reduce the size, and therefore capital costs of the 'required' subtropical, irrigated forests, and consequently can result in a still "lower tax per gallon of gas."

Acknowledgements The authors thank Dr. J. Hansen for making the facilities of GISS, and access to GSFC/NASA Center for Computer Sciences, available for these studies; and Drs. L. Druyan, A. DelGenio, and D. Hillel, of GISS, NASA, NY, NY, and Dr. R. Anthes of UCAR, Boulder, CO, for helpful reviews of drafts of this manuscript.

\section{*Legend for Online QuickTime Animations (Ornstein et al. 2009)}

Animations of 10-year average precipitation anomalies.

$\mathrm{SRF}(\mathrm{FO})$. $\mathrm{mov}$ is for SRF (FO). SRF(DCO).mov is for SRF (DCO). AuRF(FO).mov is for AuRF (FO). SRF/AuRF(FO).mov is for SRT/AuRF (FO).

In all cases, the first frame is a 10-year annual average, corresponding to Figs. $3 \mathrm{a}, \mathrm{b}$ and $(5 \mathrm{c}$ and 9), respectively, of the main text. The next 12 frames are 10-year monthly averages, January through December. Color scales are 'nonlinear', and may be of differing magnitude in some frames (the scale used is indicated within each frame) to emphasize both small teleconnections and other small anomalies (and unfortunately 'noise') as well as the large differences. The lower, right-hand corner displays the magnitudes of the minimum and maximum values of the precipitation anomalies for each frame. $(D C O=$ Dynamical Coupled Ocean. $F O=$ Fixed Ocean, with the same set of local 10-year averaged observed monthly SSTs, reused for each of the 10 years.)

Note: With QuickTime animations, you may select the 'slider' to move backwards or forwards to view individual frames.

Open Access This article is distributed under the terms of the Creative Commons Attribution Noncommercial License which permits any noncommercial use, distribution, and reproduction in any medium, provided the original author(s) and source are credited.

\footnotetext{
${ }^{7}$ CAFE (Corporate Average Fuel Economy): National Highway Traffic Safety Administration. US Dept. Transp. (2006), http://www.nhtsa.dot.gov/portal/site/nhtsa/menuitem.d0b5a45b55bfbe582f $57529 \mathrm{cdba046a0/}$

${ }^{8} 2007$ Energy Act H.R. 6, http://www.govtrack.us/data/us/bills.text/110/h/h6.pdf
} 


\section{References}

Abu-Zeid K, Wagdy A, Elbadawy O, Abdel-Meguid A (2004) State of the water in the Arab region. CEDARE, http://www.idrc.ca/uploads/user-S/11114806841arabstatewater1.pdf

Allen RJ (1983) Monsoon and teleconnection variability over Australasia during the southern hemisphere summers of 1973-77. Mon Weather Rev 111:113-142

Alley R et al (2007) IPCC summary for policy makers. IPCC Secretariat, Geneva, http://www.ipcc.ch

Anthes RA (1984) Enhancement of convective precipitation by mesoscale variations in vegetative covering in semiarid regions. J Clim Appl Meteorol 23:541-554

Anthes RA (1993) The global trajectory. Bul Am Meteo Soc 74:1121-1130, http://www.ucar.edu/ pres/traject.html

Axtell RL, McRae GJ (2006) Changing how we discount to make public policy more responsive to citizens' time preferences. Regulatory Analysis 06-01 AEI Brookings Joint Center for Regulatory Studies, http://www.aei-brookings.org/publications/abstract.php?pid=1049

Bala G, Caldeira K, Wickett M, Phillips TJ, Lobell DB, Delire C, Mirin A (2007) Combined climate and carbon-cycle effects of large-scale deforestation. Proc Natl Acad Sci 104:6550-6555

Battle M, Bender ML, Trans PP, White JWC, Ellis JT, Conway T, Francey RJ (2000) Global carbon sinks and their variability inferred from atmospheric O2 and ?13C. Science 287:2467-2470

Benyon RG (1999) Nighttime water use in an irrigated Eucalyptus grandis plantation. Tree Physiol 19:853-859

Beyerle U, Rueedi J, Leuenberger M (2003) Evidence for periods of wetter and cooler climate in the Sahel between 6 and 40 kyr BP derived from groundwater. Geophys Res Lett 30:1173-1177

Braconnot P, Joussaime S, Marti O, deNoblet-Ducoudre N (1999) Synergistic feedbacks from ocean and vegetation on the African monsoon response to mid-Holocene insolation. Geophys Res Lett 26:2481-2484

Bradstock R, Williams J, Gill O (2002) Des: Flammable Australia. The fire regimes and biodiversity of a continent. Cambridge University Press, Cambridge, 462 pp

Cannell MGR (1999) Environmental impacts of forest monocultures: water use, acidification, wildlife conservation, and carbon storage. New Forests 17:239-262

CEOS TIGER (2004) CEOS TIGER-Workshop. Space Technologies for Water Resources Management in Africa, 8-11 November 2004, http://www.tiger.esa.int/pdf/12_AQ_Pretoria_GAF_ del.pdf

Charney J (1975) Dynamics of deserts and drought in the Sahel. Q J Meteor Soc 101:193-202

Charney J, Stone PH, Quirk WJ (1975) Drought in the Sahara: a biogeophysical feedback mechanism. Science 187:434-435

Cifelli R, Smull BF, Lang TJ, Rutledge SA, Zipser EJ (2007) 12A.3 Radar observations of convection in large-scale disturbance during NAMMA. In: Proc. 33rd conf. on radar meteor, session 12A, Aug. 10, http://ams.confex.com/ams/pdfpapers/123725.pdf

Claussen M (1997) Modelling biogeophysical feedback in the African and Indian Monsoon region. Clim Dyn 13:247-257

Cook KH (1999) Generation of the African easterly jet and its role in determining West African precipitation. J Clim 12:1165-1184

Cook KH, Vizy EK (2006) Coupled model simulations of West African monsoon system: 20th century simulations and 21st century predictions. J Clim 19:3681-3703

Cook KH, Neary N, Vizy EK (2003) Mesoscale modeling of the African humid period. CLIVAR Exchanges 8:27-28

Drobinski P, Sultan B, Janicot S (2005) The role of the Hoggar massif in the West African monsoon onset. Geophys Res Lett 32:L01705.1-L01705.5

Druyan LM (1991) The sensitivity of sub-Saharan precipitation to Atlantic SST. Clim Change 18: 17-36

Duryan LM, Fulakeza M, Lonergan P (2004) Land surface influences on the West African summer monsoon: implications for synoptic disturbances. Meteorol Atmos Phys 86:261-273

Folger P (2007) Direct carbon sequestration: capturing and storing $\mathrm{CO}_{2}$. Congressional Research Service, Jan. 27, http://ncseonline.org/NLE/CRSreports/07March/RL33801.pdf

Forrester DI, Bauhus J, Cowie AL, Vanclay JK (2006) Mixed-species plantations of Eucalyptus with nitrogen-fixing trees: a review. Forest Ecol Man 233:211-230

Friend AD, Kiang NY (2005) Land surface model development for the GISS GCM: effects of improved canopy physiology on simulated climate. J Clim 18:2883-2902 
Gopalakrishnan SG, Bacon DP, Ahmad NN, Boybeyi Z, Dunn TJ, Hall MS, Jin YP, Lee CS, Mays DE, Madala RV, Sarma A, Turner MD, Wait TR (2002) An operational multiscale hurricane forecasting system. Mon Weath Rev 130:1830-1847

Gough C, Shackley S (2005) An integrated assessment of carbon dioxide capture and storage in the UK. Technical Report 47, Tyndall Project T2/21, October, http://tyndall.ac.uk/ research/theme2/final_reports/t2_21.pdf

Gu G, Adler RF (2004) Seasonal evolution and variability associated with the West African Monsoon System. J Climate 17:3364-3377

Hall T, Jewson S (2005) Statistical modelling of tropical cyclone tracks: a semi-parametric model for the mean trajectory. Atmos Ocean Phys, arXiv:physics/0503231v1

Hansen JE (2007) Scientific reticence and sea level rise. Eviron Res Lett 2(2):024002

Hansen J, Sato M (2004) Greenhouse gas growth rates. Proc Natl Acad Sci 101:16109-16114

Hansen J, Johnson D, Lacis A, Lebedeff S, Lee P, Rind D, Russell G (1981) Climate impact of increasing atmospheric carbon dioxide. Science 213:957-966

Hansen J, Russell G, Rind D, Stone P, Lacis A, Lebedeff S, Ruedy R, Travis L (1983) Efficient three-dimensional global models for climate studies: models I and II. Mon Weath Rev 111:609662, http://www.giss.nasa.gov/tools/modelii/

Hansen J, Sato M, Ruedy R, Nazarenko L, Lacis A, Schmidt GA, Russell G, Aleinov I, Bauer M, Bauer S, Bell N, Cairns B, Canuto V, Chandler M, Cheng Y, Del Genio A, Faluvegi G, Fleming E, Friend A, Hall T, Jackman C, Kelley M, Kiang NY, Koch D, Lean J, Lerner J, Lo K, Menon S, Miller RL, Minnis P, Novakov T, Oinas V, Perlwitz Ja, Perlwitz Ju, Rind D, Romanou A, Shindell D, Stone P, Sun S, Tausnev N, Thresher D, Wielicki B, Wong T, Yao M, Zhang S (2005) Efficacy of climate forcings. J Geophys Res 110:D18104.1-D18104.45

Hariri AR, Brown SM, Williamson DE, Flory JD, de Wit H, Manuck SB (2006) Preference for immediate over delayed rewards is associated with magnitude of ventral striatal activity. J Neurosci 26:13213-13217

Hegerl GC, Zwiers FW, Braconnot P, Gillett NP, Luo Y, Orsini JAM, Nicholls N, Penner JE, and Stott PA (2007) Chapter 9: understanding and attributing climate change. In: Solomon S, Qin D, Manning M, Chen Z, Marquis M, Averyt KB, Tignor M, Miller HL (eds) Climate change: the physical science basis. Contribution of working group I to the fourth assessment report of the intergovernmental panel on climate change. Cambridge University Press, Cambridge

Hopkins M (2007) Climate sceptics switch focus to economics. Nature 445:582

Howell TA (2001) Enhancing water use efficiency in irrigated agriculture. Agron J 93:281-289

Howell TA (2003) Irrigation efficiency. In: Stewart BA, Howell TA (eds) Encyclopedia of water science. Marcel Dekker, New York, pp 467-472

Janicot S (1992) Spatiotemporal variability of West African rainfall. Part II: associated surface and airmass characteristics. J Climate 5:499-511

Kerr RA (2000) A North Atlantic climate pacemaker for centuries. Science 288:1984-1985

Kerr RA (2006) Global warming may be homing in on Atlantic hurricanes. Science 314:910-911

Kerr RA (2007) A dose of dust that quieted an entire hurricane season? Science 315:1351

Kiang NY, Koster RD, Moorcroft PR, Ni-Meister W, Rind DH, Aleinov I, Kharecha P, Kim Y (2007) Ent: a dynamic terrestrial ecosystem model for coupling with GCMs. NASA modeling, analysis and prediction (MAP) Science team meeting, Adelphi, MD, March 6-9, 2007. http://www.agu.org/cgi-bin/SFgate/SFgate? \&listenv=table\&multiple=1\&range=1\&directget=1\& application $=$ fm $06 \&$ database $=\% 2$ Fdata $\% 2$ Fepubs $\% 2$ Fwais $\% 2$ Findexes $\% 2$ Ffm $06 \% 2$ Ffm $06 \&$ maxhits $=200 \&=\% 22 B 51 \mathrm{~A}-0301 \% 22$

Koren I, Kaufman YJ, Washington R, Todd MC, Rudich Y, Vanderlei-Martins J, Rosenfeld D (2006) The Bodélé depression: a single spot in the Sahara that provides most of the mineral dust to the Amazon forest. Env Res Lett 1:014005 (5 pp)

Kuper R, Kropelin S (2006) Climate-controlled Holocene occupation in the Sahara: motor of Africa's evolution. Sciencexpress, http://www.sciencexpress.org/20 July 2006/Page 1/10.1126/ science.1130989

Kutzbach JE, Liu Z (1997) Response of the African monsoon to orbital forcing and ocean feedbacks in the middle Holocene. Science 278:440-443

Lau KM, Bua W (2004) Mechanisms of monsoon-Southern Oscillation coupling: insights from GCM experiments. Clim Dynam 14:759-779

Lau KM, Yang S (1996) The Asian monsoon and the predictability of the tropical ocean-atmosphere system. Quart J Roy Meteor Soc 122:945-957 
Lebel T, Redelsperger J-L, Thorncroft C (2005) The international science plan for African Monsoon Multidisciplinary Analyses (AMMA). May, http:/www.lthe.hmg.inpg.fr/catch/publication/ reference_doc/AMMA_ISP_Final_May2005.pdf

Lindsay RW, Zhang J (2005) The thinning of Arctic sea ice, 1988-2003: have we passed a tipping point? J Clim 18:4879-4894

Lynch-Stieglitz M (1994) The development and validation of a simple snow model for the GISS GCM. J Clim 7:1842-1855

Malkovic T (2007) The water down under. NOVA Science in the News, Feb., http://www.science. org.au/nova/100/100key.htm

Matthews AJ (2004) Interseasonal variability over tropical Africa during northern summer. J Climate $17: 2427-2440$

Murder EG (1975) Physiology and ecology of free-living, nitrogen-fixing bacteria. In: Stewart WDP (ed) Nitrogen fixation by free-living micro-organisms. Cambridge University Press, New York

Nicholson SE (1981) Rainfall and atmospheric circulation during drought periods and wetter years in West Africa. Mon Wea Rev 109:2191-2208

Nicholson SE (1993) An overview of African rainfall fluctuations of the last decade. J Climate 6:1463-1466

Nicholson SE (2006) Monsoon systems and continental rainfall over equatorial Africa. In: Proceedings of 8 ICSHMO, Foz do Iguaçu, Brazil, INPE, April, pp 24-28

Nordhaus W (2007) Critical assumptions in the stern review on climate change. Science 317:201-202

Null J (2004) El Niño \& La Niña years: a consensus list. Golden Gate Weather Services, Oct, http://ggweather.com/enso/years.htm

Ornstein L (1967) The population explosion, conservative eugenics and human evolution. Biosciences 17:461-464, http://www.pipeline.com/ lenornst/PopulationExplosion.html

Ornstein L (1980) US Patent 4,182,357 January 8, 1980, http:/www.pipeline.com/ lenornst/Irristat. html

Ornstein L (1987) Tenuous but contingent connections. Electrophoresis 8:3-13, http://www.pipeline. com/ lenornst/Tenuous.pdf

Ornstein L (2009) Replacing coal with wood to end global warming: sustainable, eco-neutral, conservation harvest of natural tree fall in old-growth forests: an editorial essay. Clim Change. doi:10.1007/s10584-009-9625-z

Ornstein L, Aleinov I, Rind D (2009) QuickTime animations.* http://data.giss.nasa.gov/afforest/

Patricola CM, Cook KH (2007) Dynamics of West African Monsoon under Mid-Holocene precessional forcings: regional climate model simulations. J Clim 20:649-716

Powers RF (1999) On the sustainability of planted forests. New Forests 17:263-306

Rind D, Lerner J, Jonas J, McLinden C (2007) Effects of resolution and model physics on tracer transports in the NASA goddard institute for space studies general circulation models. J Geophys Res 112:D09315

Rodwell MJ, Folland CK (2003) Atlantic air-sea interaction and model validation. Ann Geophys 46:47-56

Rosenzweig C, Abramopoulos F (1997) Land-surface model development for the GISS GCM. J Clim 10:2040-2054

Russell GL, Miller JR, Rind D (1995) A coupled atmosphere-ocean model for transient climate change studies. Atmos Ocean 33:683-730

Santer BD, Thorne PW, Hamberger L, Taylor KE, Wigley TML, Lanzante JR, Solomon S, Free M, Gleckler PJ, Jones PD, Karl TR, Klein SA, Mears C, Nychaka D, Schmidt GA, Sherwood SC, Wentz FJ (2008) Consistency of modelled and observed temperature trends in the tropical troposphere. Int J Climatol 28:1703-1722. doi:10.1002/joc.1756

Santos AMP, Kazmin AS, Peliz A (2005) Decadal changes in Canary upwelling system as revealed by satellite observations: their impact on productivity. J Marine Res 63:359-379

Schmidt GA, Ruedy R, Hansen JE, Aleinov I, Bell N, Bauer M, Bauer S, Cairns B, Canuto V, Cheng Y, Del Genio A, Faluvegi G, Friend AD, Hall TM, Hu Y, Kelley M, Kiang NY, Koch D, Lacis AA, Lerner J, Lo KK, Miller RL, Nazarenko L, Oinas V, Perlwitz Ja, Perlwitz Ju, Rind D, Romanou A, Russell GL, Sato M, Shindell DT, Stone PH, Sun S, Tausnev N, Thresher D, Yao MS (2006) Present day atmospheric simulations using GISS ModelE: comparison to in-situ, satellite and reanalysis data. J Climate 19:153-192, http://www.giss.nasa.gov/tools/modelE/

Service RF (2006) Desalination freshens up. Science 313:1088-1090

Stape JL, Binkley D, Ryan MG (2004a) Eucalyptus production and the supply, use and efficiency of use of water, light and nitrogen across a geographic gradient in Brazil. For Ecol Man 193:17-31 
Stape JL, Ryan MG, Binkley D (2004b) Testing the utility of the 3-PG model for growth of Eucalyptus grandis $\times$ urophylla with natural and manipulated supplies of water and nutrients. For Ecol Man 193:219-234

Stern N, Taylor C (2007) Climate change: risk, ethics and the stern review. Science 317:203-204

Thompson C (2007) Motorhead messiah. Fast Company 120:74, http://www.fastcompany.com/ magazine/120/motorhead-messiah.html

Titchner HA, Thorne PW, McCarthy MP, Tett SFB (2009) Critically reassessing tropospheric temperature trends from radiosondes using realistic validation experiments. J Climate 22:465-483

Vizy EK, Cook KH (2001) Mechanisms by which Gulf of Guinea and Eastern North Atlantic sea surface temperature anomalies can influence African rainfall. J Clim 14:795-821

Wikipedia (2009a) Nile. http://en.wikipedia.org/wiki/Nile

Wikipedia (2009b) Power plants. http://en.wikipedia.org/wiki/Economics_of_new_nuclear_power_ plants

Wikipedia (2009c) Ecological footprint. http://en.wikipedia.org/wiki/Ecological_footprint

Wikipedia (2009d) Renewable resources. http://en.wikipedia.org/wiki/Renewable_resources

Willoughby HE (2007) Forecasting hurricane intensity and impacts. Science 315:1232-1233

Zipser E (2006) A nursery for hurricanes. Univ. Utah News Report, Aug. 8, http://unews.utah. $\mathrm{edu} / \mathrm{p} / \mathrm{?}=080806-2$

Zuppi GM, Sacchi E (2004) Hydrology as a climate recorder: Sahara-Sahel (North Africa) and the Po Plain (Northern Italy). Glob Planet Change 40:79-91 